\title{
التنسيط لمعدل الاستخدام ونسبة الهالك في إنتاج الملابس الجاهزة المعدة للتصدير وتأثيره على النواحي الاقتصادية
}

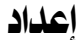

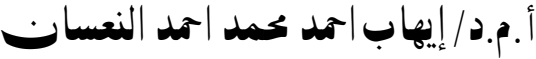

$$
\begin{aligned}
& \text { أستاذ مساعد بقسم الملابس والنسيج } \\
& \text { كلية الاقتصاد المنزلي - جامعة المنوفية }
\end{aligned}
$$

مجلة بحوث التربية النوعية ـ جامعة المنصورة

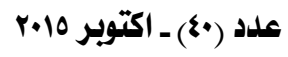




\title{
التنميط لمعدل الاستخدام ونسبة الهالك في إنتاج الملابس الجاهزة المعدة للتصدير وتأثيره على النواحي الاقتصادية
}

\author{
إعداد

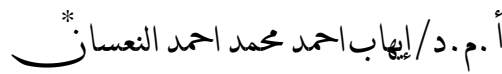

\section{ملفص البمث:}

يعد التصدير من أهم إستراتيجيات التوغل يِّا الأسواق الدولية كمها أنه أحسد أهـم الأهـداف

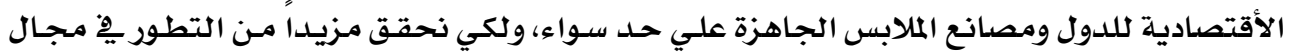

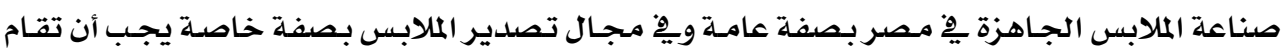

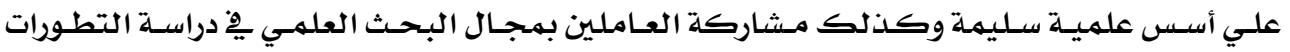

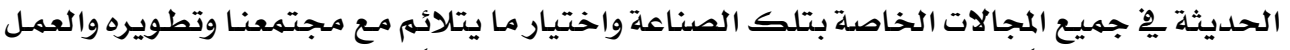

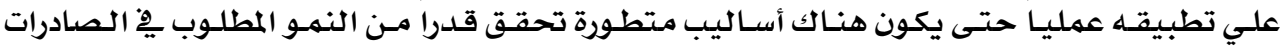

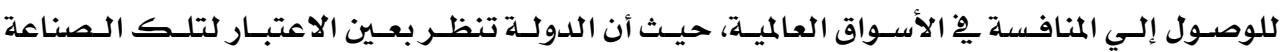

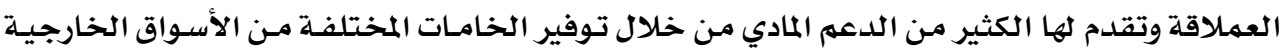

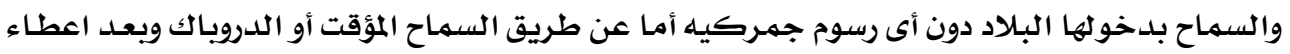

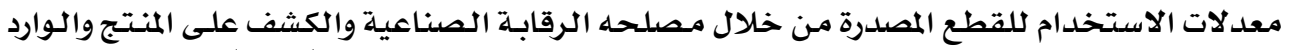

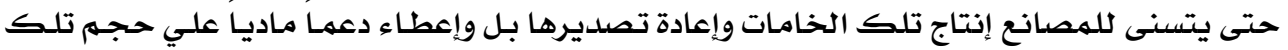

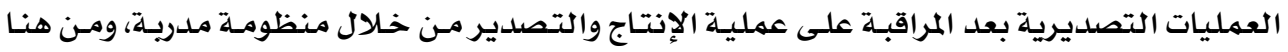

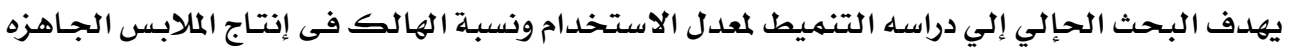

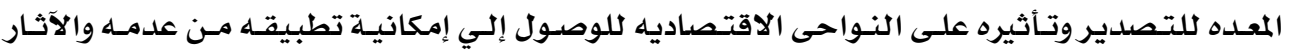

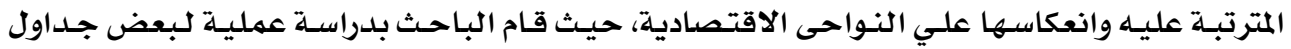

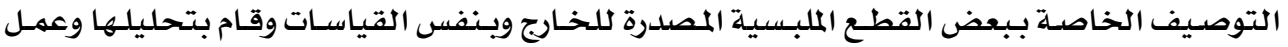

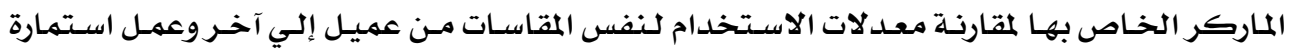

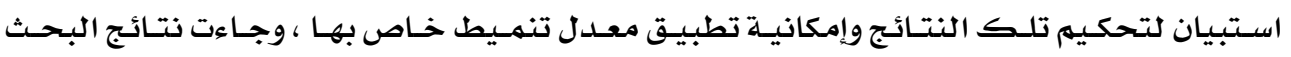

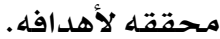

\section{الاقدهمة ومشكلة البحث:-}

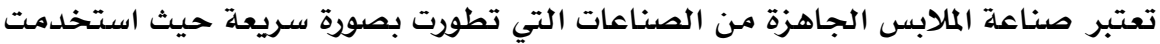

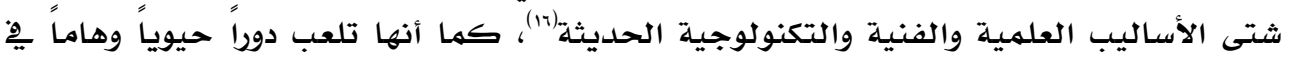

" أستاذ مساعد بقسم الملابس والنسيج- كلية الاقتصاد المنزلي - جامعة المنوفية 


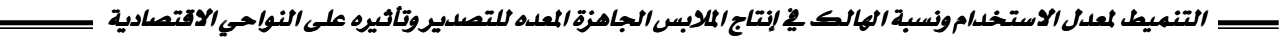
إقتصاديات الدول النامية وخاصسة ج.م.ع ولذلك أعطتها الدولة إهتماماً كبيراً ودعماً واضحاً للنهوض بها"، وتعتبر صناعة الملابس من أهم مصسادر الدخل القومي وتوفير العمله الصعبـه حيث

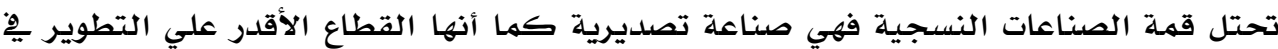
مصر (10) حيث أن أكثر مـن VV ٪ من الصناعات الوطنيـة المصدرة للخارج هى تلك الصناعة حيث تصدر إلي دول العالم كدول الاتحاد الأوروبي والولايات المتحدة الأمريكية وغيرها (r)، ويعد التصدير مـن من أهم إستراتيحيات التوغل يِ الأسواق الدولية وأحد أهم الأهداف الأقتصدادية بالنسبـة للدول ومصانع

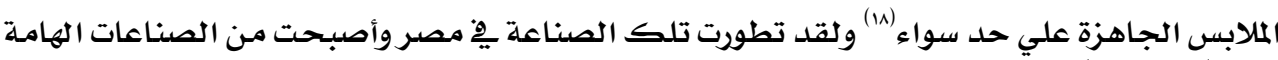

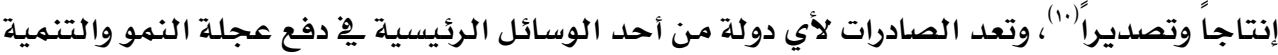
الأقتصادية، كما يمثل التصدير نقطة الإنطلاق إلي الأسواق العالمية مها يعود علي الدولة مـن زيادة هِ الأرباح والعملة الصعبة(r)، ولذلك أصبيح التصدير الهدف الذي يسعى إليه منتتجو المنسوجات

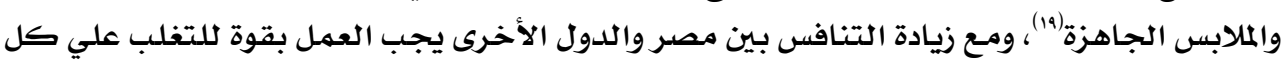

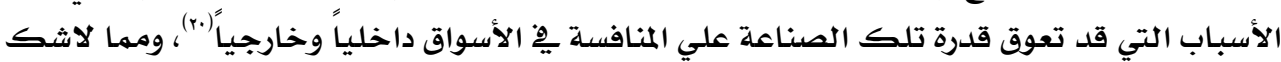
فيه أنه كلما كانت قدرة تلك الصناعة عالية ِِّ مجال التصدير والمنافسة كلها زادت فرص نهو

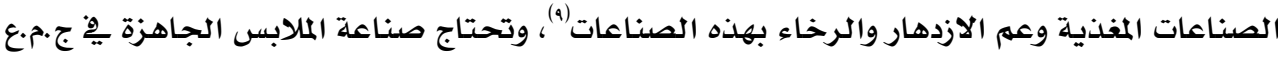
إلىي مواكبة الإتجاهات والأسـاليب التكنولوجية والتطبيقية الحديثة حتى تصبـح قادرة علي المنافسـة

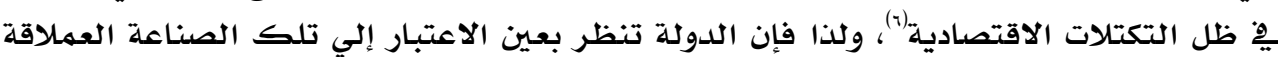
وتقدم لها الكثير من الدعم المادي والمعنوي مـن خلال توفير الخامات الأسـاسية والمساعدة بكافة صورها من الأسواق الخارجية دون أي رسوم جمركية إمـا عن طريق السهاح المؤقت أو الدروباك حتى يتسنى

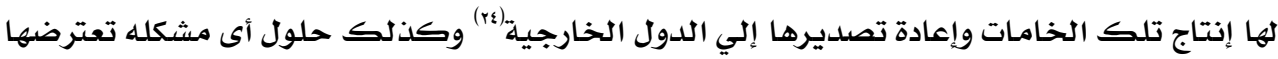
عن طريق جهاز تحديث الصناعه الذى يساهم بنسبه تصل إلي •9٪ فى تحديث تلك المصانع وكذلك تعطى الدولة الدعم المادي علي حجم تلك العمليات التصديرية وذلك بعد المراقبة الجيدة لعمليـة الإنتاج والتصدير للتأكد مـن أن تلك الخامـات الوارده مـن الخارج تم تصنيعها وليس بيعها

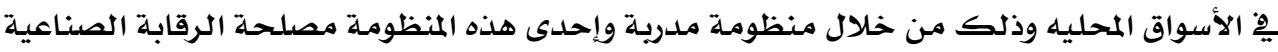
هِ مصر وهي من المنشآت الحكومية الهامة التي لها تأثير مباشر علي نجاح تلك الصناعة وإزدهارها

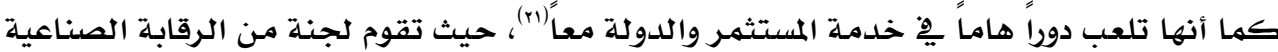
بـاتتأكد من مطابقة الماركر والمقاسـات وكشف التعبئسه للخام الوارد من الخارج وكذلك تقوم بهـراجعـة جميع أجزاء البـاترون وأسلوب التعشيق وتحدد معدل الاستخدام وكذلك نسبـة الهالك وأوامر التشخيل المعدة للتصدير للتأكد من مطابقة المنتج للخامـات التي يتم إستيرادها ومطابقة أرقام الأتواب التي تم تشغيلها وذلك له أهمية قصوى لعدم إهدار المال العام ولخلق مناخ تصديري

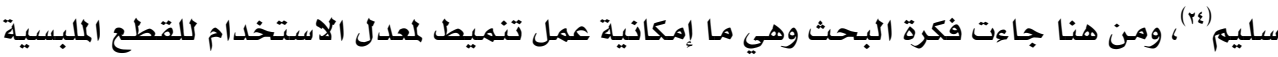
المختلفة بها أنها بنفس القياسـات ونفس عروض الأقمشة وذلك يْ مجال التصلدير لتسهيل عملية التصلير علي المستثمر وكذلك تقليل الضغط الواقع علي مصلحة الرقابة الصناعية المنوطه بالمراقبـه على جميع المصانع فى ج·مع والدولة أيضاً وهذا هو الدور الأسـاسي الذي يجب أن يلعبـا 


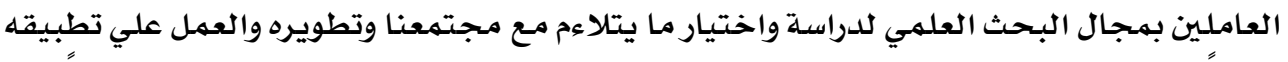

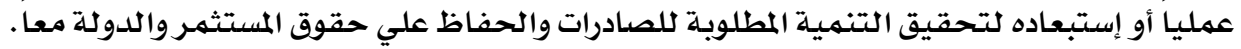

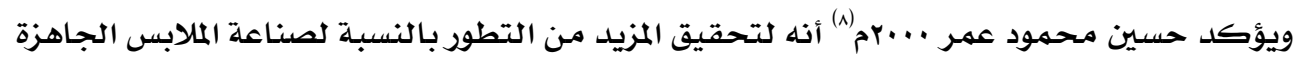

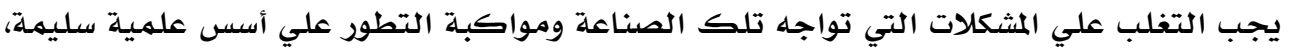

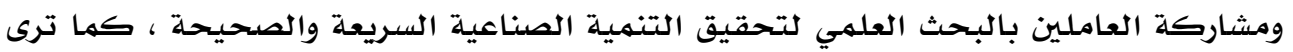

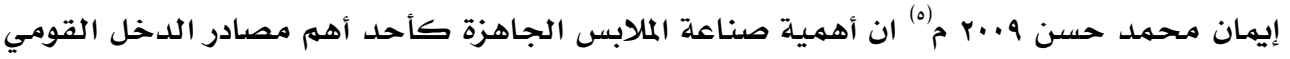

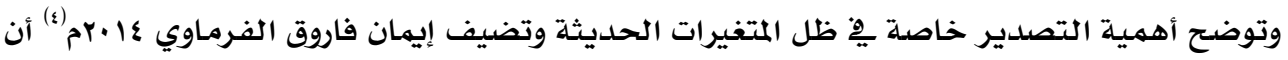

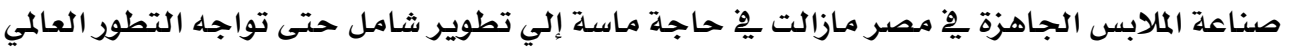

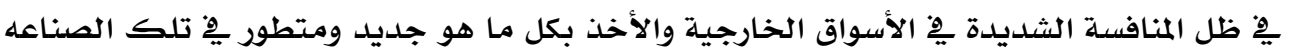

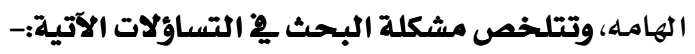

1. ما إمكانية تطبيق التنميط لمعدل الاستخدام ِِّ مجال الملابس الجاهزة الخاصدة بالتصدير؟

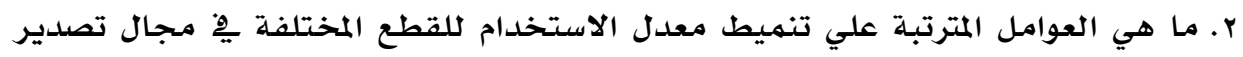

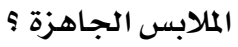

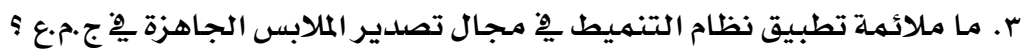

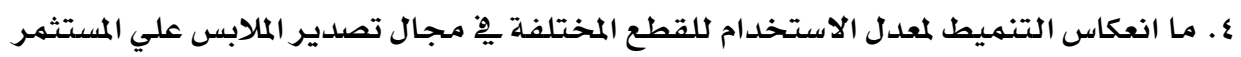

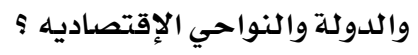

\section{أهداف البحث وأهميتهه:-}

ا. الوقوف علي أهم الأسباب التي قد تؤثر علي مصلحة الدولة من خلال تطبيق تنميط معدل

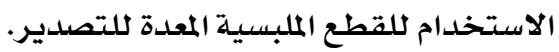
r.الوصول إلي العوامل المترتبة علي تنميط القطع الملبسية المختلفة فِّة مجال تصدير الملابس الجاهزة.

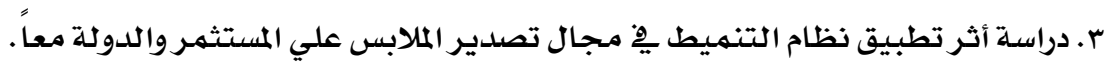

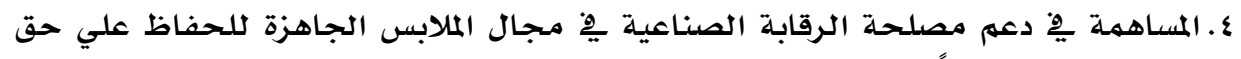
الدولة والمستثمر معاً. ه. إضافة دراسة تحليلية جديدة إلي المصانع المتخصصة والهيئات الرقابية لتحديديد العوامل

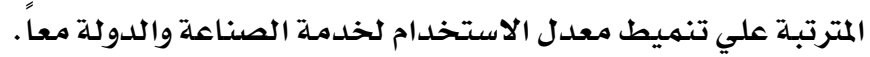

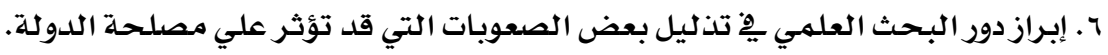

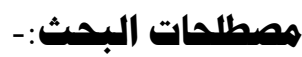
• التنميط:

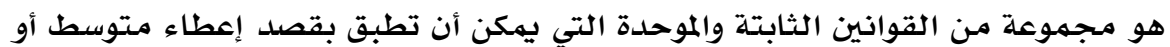

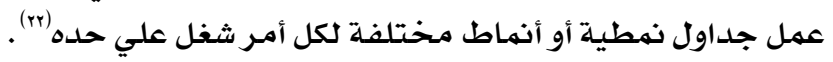


هو أحد أهم الأهداف الاقتصادية لأي دولة وهو أهم عمليات التبادل التجاري للسلع

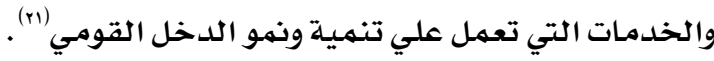

\section{• مصلحة الرقابة الصناعية:}

هي أحد المصالح الحكومية ِِِّ ج.م.ع وقد تأسست عام 1907م وهي المسئولة عن الرقابة علي

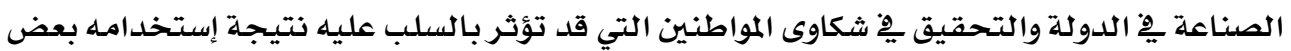

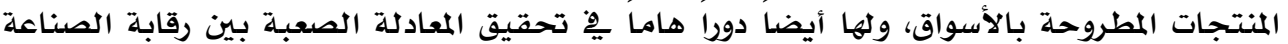

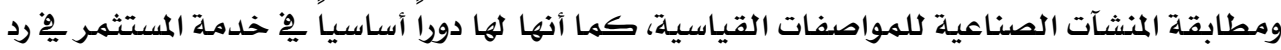
بعض المستحقات الخاصة به مما يعود عليه بالنفع وكذلك المحافظة علي حق الدولة وعدم إهدار

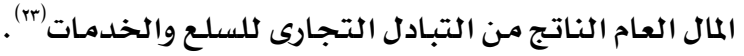
• السماح المؤقت:

هو الإعفاء بصفه مؤقته من الضرائب الجمركيه وغيرها من الضرائب والرسوم لما يتم

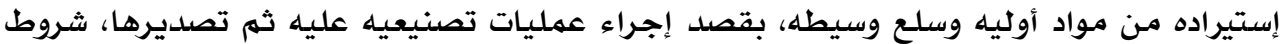

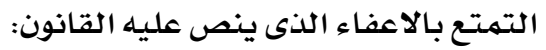

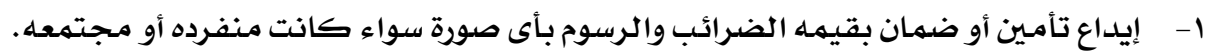

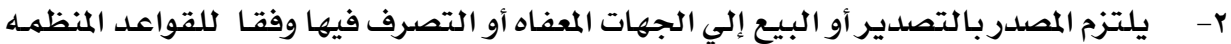

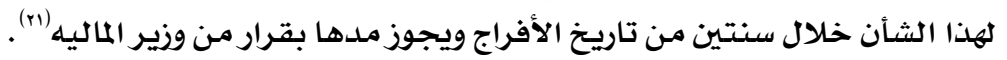

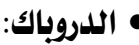

نظام رد الضرائب والرسوم الجمركيه ورسوم الخدمات ويشمل حالتين الأولى هى المواد

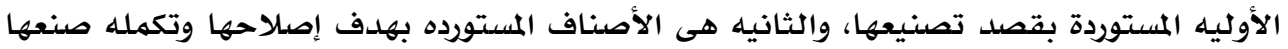
حسب العمليات الصناعيد (rs) الموليه حدود البمث:-

يقتصر البحث الحالي علي دراسـة العوامل المترتبة علي تنميط القطع الملبسية المختلفة يِّي

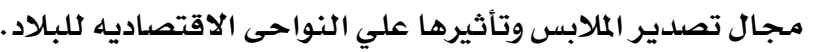

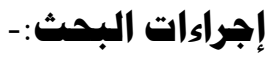
منهج البحث:

يتبع هذا البحث المنهج التحليلي التطبيقي من خلال إجراء بعض التطبيقات العملية

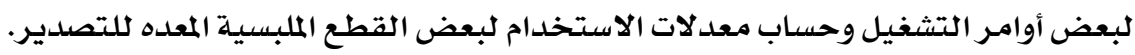




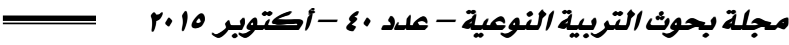

عينة البحث:

تتكون عينة البحث من مجموعة من مصانع المابلابس الجاهزة التى تعمل ِِّْ مجال التصدير

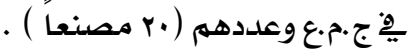

$$
\begin{aligned}
& \text { أدوات البحث:ـ }
\end{aligned}
$$

إعداد استبيان بهدف التعرف علي آراء السادة أعضاء هيئة التدريس المتخصصين والمحكمين

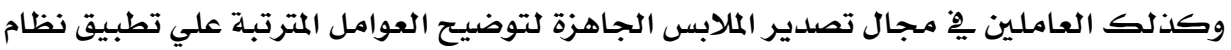

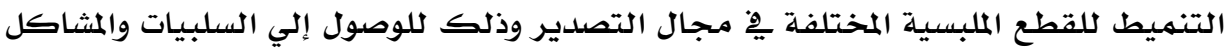

المتعلقة بتنفيذ التنميط.

- تكونت استمارة الاستبيان من أريعة محاورويحتوى كل محور علي اريعة بنود وذلك كما يلى : • المحور الاول : إمكانيه تنميط معدل الاستخدام وذسبه الهالك فى مجال تصدير الملابس الجاهزة:

$$
\text { ويتضمن أريع بنود تدور حول: }
$$

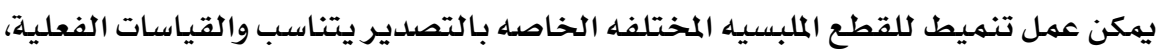

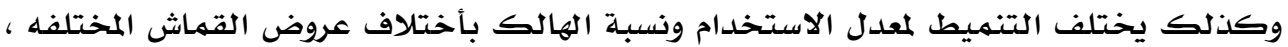

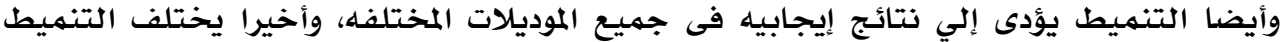

$$
\text { باختلاف الدوله المصدر إليها المنتجج · لمديط }
$$

•المحور الثانى:العوامل المترتبه على تتميط معدل الاستخدام ونسبه الهالك فى مجال تصدير الملابس فى ج.م.ع:

$$
\text { ويتضمن أربع بنود تدور حول: }
$$

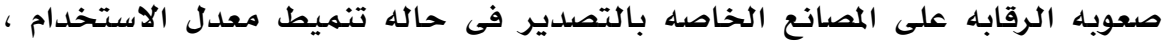

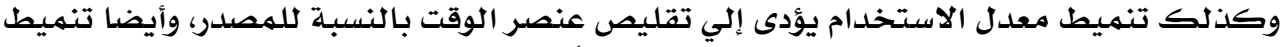

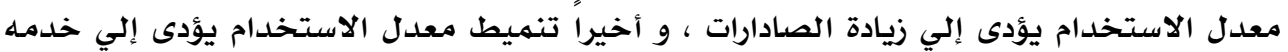

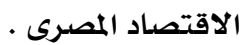

\section{• المحور الثالث : ملائهه تطبيق نظام التنميط فى مجال تصدير الملابس الجاهزة فى ج.م.ع}

$$
\text { ويتضمن أريع بنود تدور حول : }
$$

ملائممه تطبيق تنميط معدل الاستخدام فى ج.م.ع ، و ملائمسه عمل جداول قياسيه ثابته

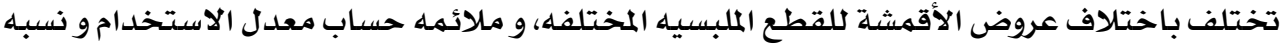
الهالك من خلال متوسطات لها، وأخيرا ملائمهه نظام التنميط وتطبيقه لمواكبه الاتجاهات والاساليب التطبيقيه الحديثله. • المحور الرابع : انعكاس التنميط لمعدل الاستخدام ونسبه الهالك على المستثمر واللدوله والمال العام

$$
\text { ويتضمن أربع بنود تدور حول: }
$$




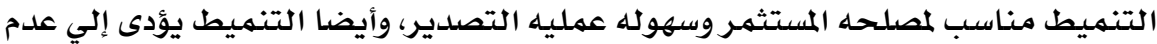

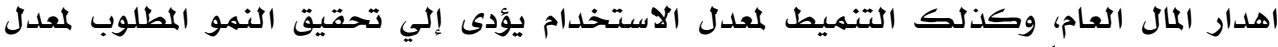

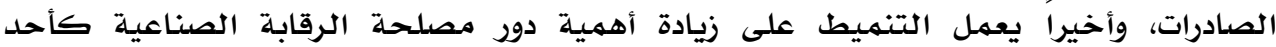
الهيئات الرقابية.

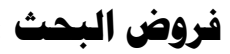

ا- توجد فروق ذات دلالة إحصائية بين متوسطات آراء المحكمين ِِّ إمكانية تنميط معدل

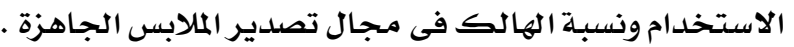

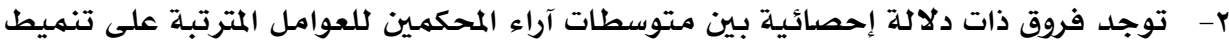

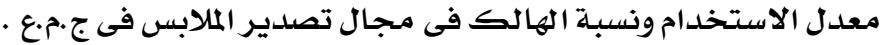

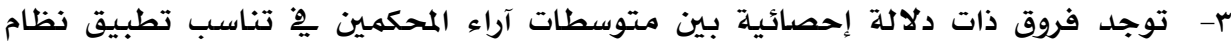

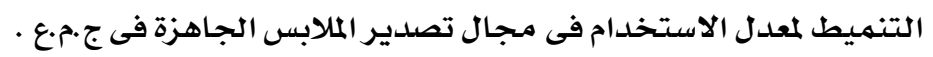

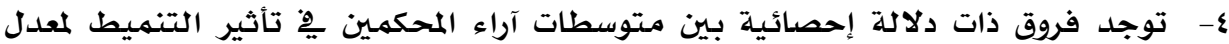

الاستخدام ونسبـة الهالك على المستثمـر والدولة والإقتصاد المصري.

\section{صدق الاستبـيان}

تم عرض الاستبيان فِ صورته الأولية علي مجموعة من الأساتذة أعضاء هيئة التدريس التحس بقسه الملابس والنسيج بكلية الاقتصاد المنزلي جامعتي حلوان والمنوفية وكذلك بعض العض العاملين

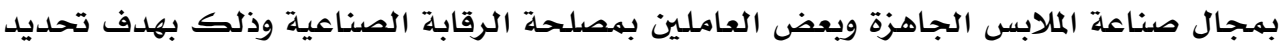

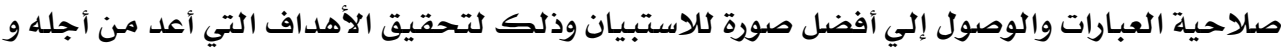

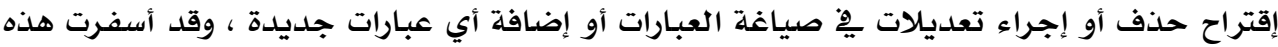

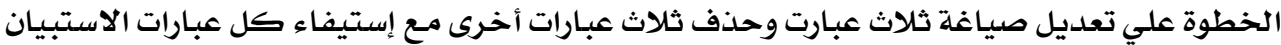

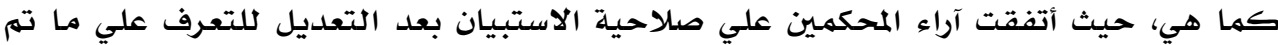

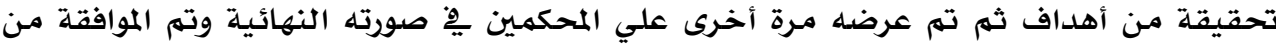
جميع المحكمين.

\section{الدراسات البسابقة}

\section{(v) دراسة حنان توفيق محمد والى r...}

تهدف الدراسـة إلي إبراز الدور الهام لصناعة الملابس الجاهزة ِِّ الاقتصاد والذي أدى إلى إلي

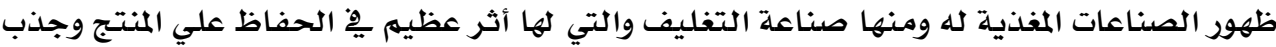
المستهلك، وقد توصلت الدراسة إلي ضرورة تطوير هذه الصناعة ومواكبة التكنولوجيا الحديثة الخاصة بها لرفع الجودة وزيادة القدرة التنافسية والتسويقية للمنتج. 
دراسة رزق عبد الله البيلي وحاتم محمد فتحي r... تهدف الدراسة إلي التعرف علي المعوقات الداخلية والخارجية التي تواجها صناعة صناعة الملابس

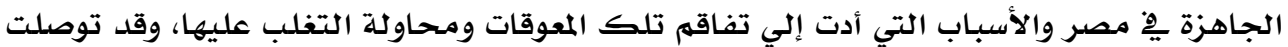

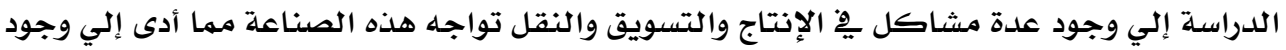
مشاكل يْ عمليات التصلدير.

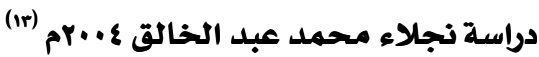

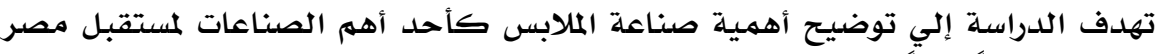

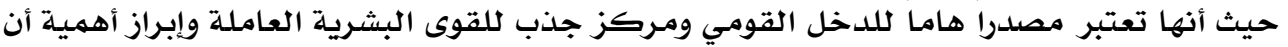

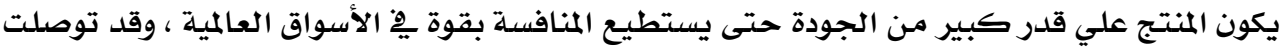

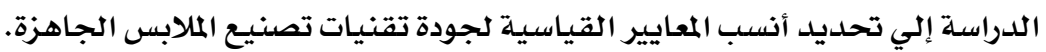

دراسة هاني محممود عبد الحميد r... تهدف الدراسة إلي الوقوف علي أهم الأسباب التي تؤدي إلي ركود المنتج المصري يِّ الأسواق

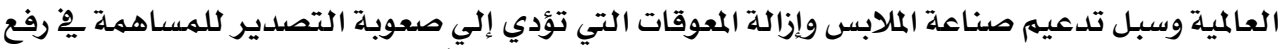

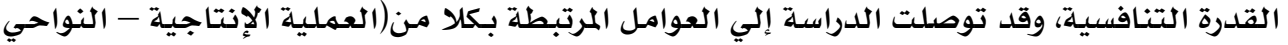

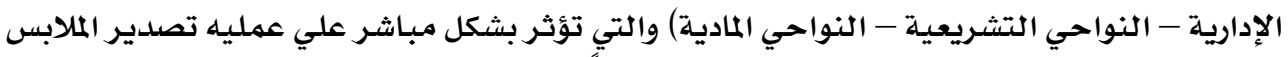

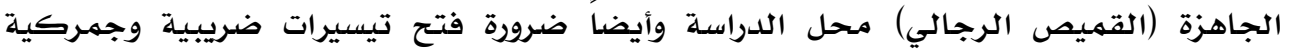

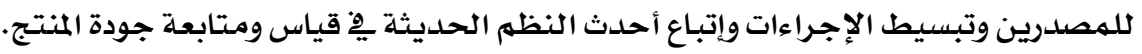
دراسة ماجد محمد كمال يوسف V... (11) تهدف الدراسـة إلي توضيح الدور الهام للتصدير لزيادة القدرة التنافسية بين مصر والدول

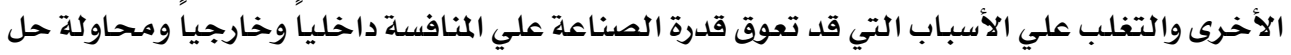

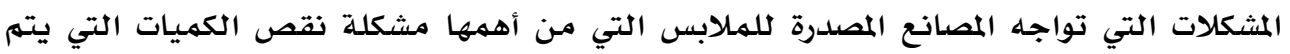

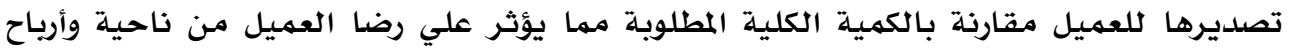

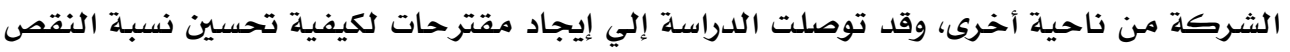

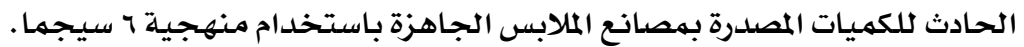

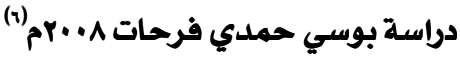

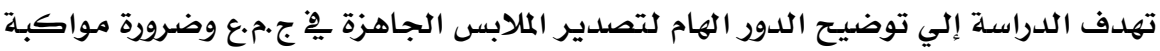

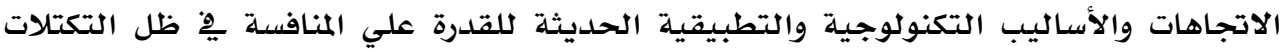

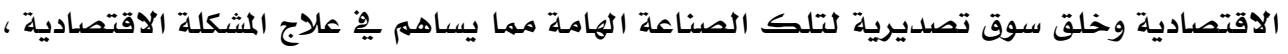

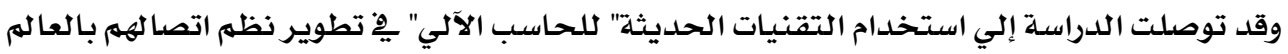

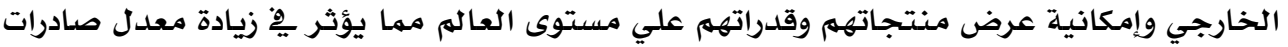


دراسـة إيمان محمد حسن 9 ه..

تهدف الدراسة إلي إبراز الطبيعة المحورية لصناعة الملابس وأثرها علي الدخل التوابل التومي

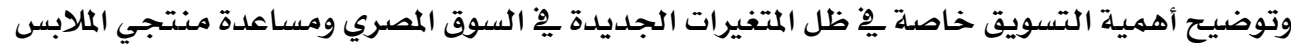

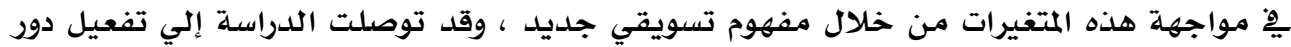

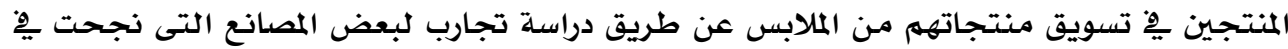
التغلب علي مشكلات السوق بحلول متطورة.

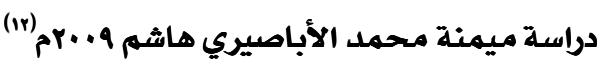
تهدف الدراسـة إلي التعرف علي أهمية صناعة الملابس الجاهزة ودورها ِِّ النهوض والتنمية

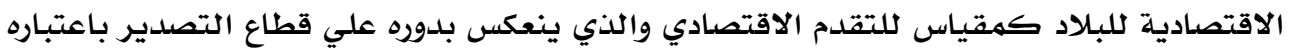

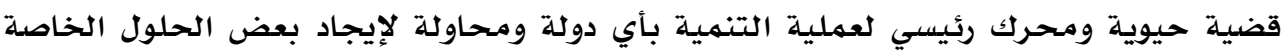

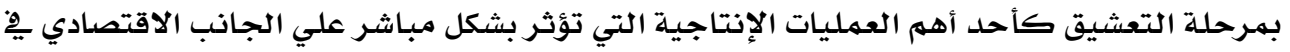

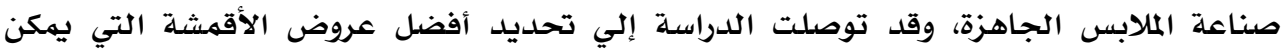

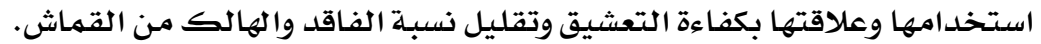
التعليق علي الدراسات السابقة:.

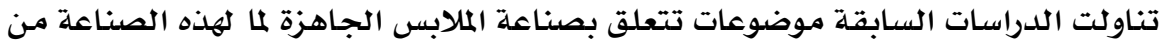

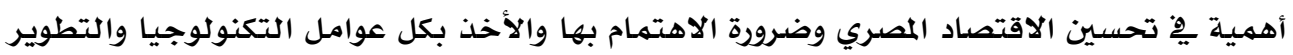
للوصول إلي إزدهار ورقي تلك الصناعة، وكذلك تناولت الدور الهام للتصدير ِِّه زيادة الدخل

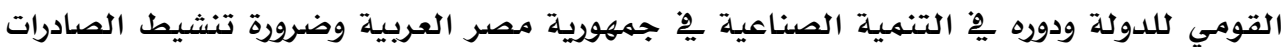

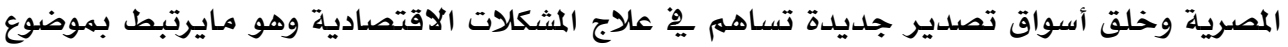
البـحث الحالي.

\section{الدراسة العمثلية :}

قام الباحث بعمل زيارة ميدانية لمجموعة من مصانع الملابس الجاهزة والتى تعمل فى مجال

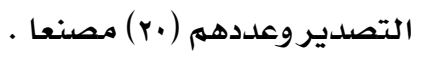

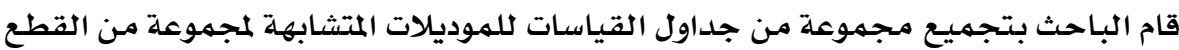

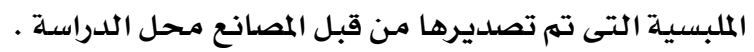

قام الباحث بتحليل تلك الجداول والموديلات وعمل دراسة لبعض الأمثلة منها وعددهم 1 وندي

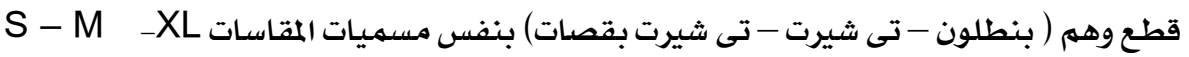

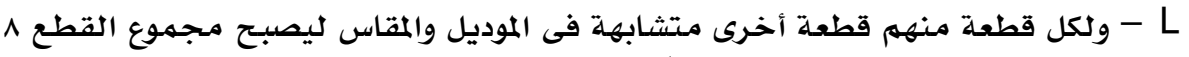

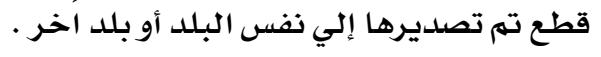

تم تحليل جداول المقاسات وعمل الباترونات الخاصدة بها وتحليلها وكذلك عمل الماركر

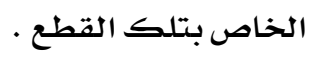




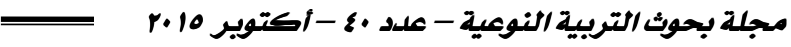

قام الباحث بعمل التعشيق والباترونات على جهاز ( جمني ) على مجموعة مـن العروض

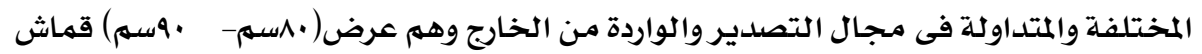

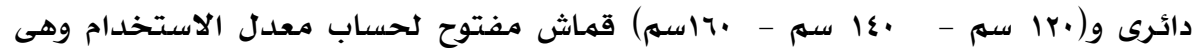

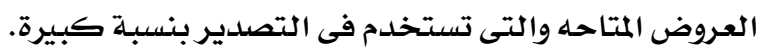

تم عمل مقارنة بين معدلات الاستخدام للقياسات المتشابهة فى المسميات وبهقارنة تلك الكاتك

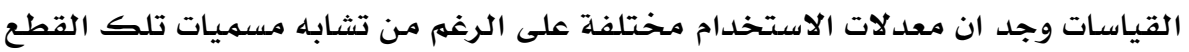

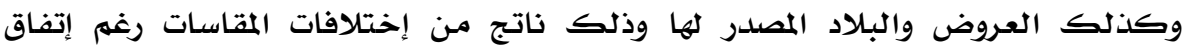
المسميات(S - M - L _XL) وذلك طبيعى باختلافها من دوله إلى أخرى وأحيانا أيضاً

$$
\text { لنفس الدولكه. }
$$

تم عرض معدلات الاستخدام والماركر على المصانع التى قامت بتصديرها من قبل للتأكد من صحمة التعشيق و تطابقه.

قام الباحث بعمل استمارة تقويم وعرضها على السادة أعضاء هيئة التدريس المتخصصين

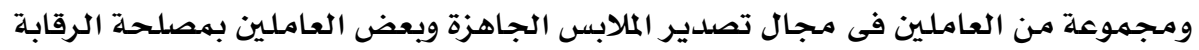

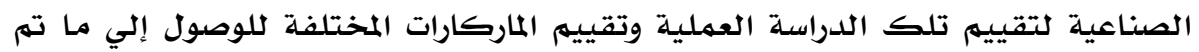
تحقيقة من أهداف . وفيما يلى عرض لبعض القطع المصدره بالفعل والتى قامت عليها الدراسها: أولا: بنطلوز مقاس (M-L-XL)

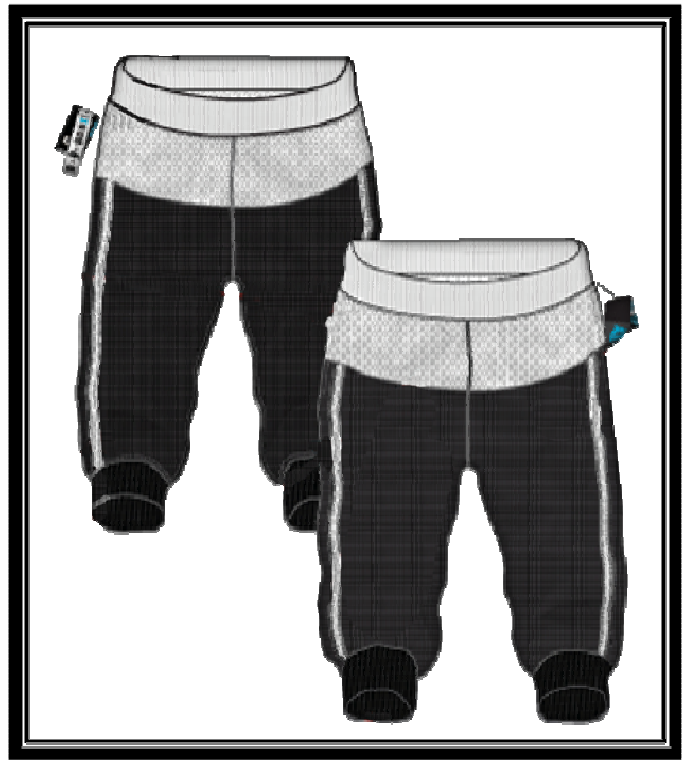

شكل رقم(1) يوضح تصميم البنطلون الأول مقاس (M-L-XL) 


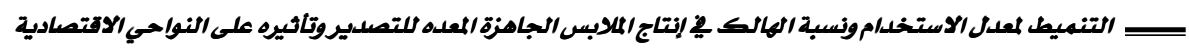
جدول رقهم( ) يوضح توصيف العميل لمقاسـات البنطلون الأول مقاس (M-L-XL) بالبوصده

\begin{tabular}{|c|c|c|c|c|}
\hline XL & $\mathrm{L}$ & M & تفاصيل المواصفات & المواصفات \\
\hline 14 & $131 / 2$ & 13 & علي امتداد أعلي الأمام و الخلف & الوسط بدوز شد \\
\hline 18 & $171 / 2$ & $161 / 2$ & & الوسط مشدود \\
\hline $191 / 2$ & $181 / 2$ & $171 / 2$ & ب بوصة أعلي الحجر الأمامي & دوران الأجناب \\
\hline 11 & $101 / 2$ & 10 & ابوصة أسفل الحجر & مقاس الفخذ \\
\hline $111 / 4$ & $107 / 8$ & $101 / 2$ & & الججر الأمامي \\
\hline $141 / 4$ & $137 / 8$ & $131 / 2$ & & 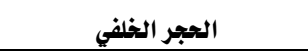 \\
\hline 2 & 2 & 2 & & عرض الكمر \\
\hline $81 / 8$ & $75 / 8$ & $71 / 4$ & • بوصة أسفل الحجر & 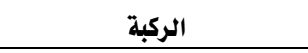 \\
\hline $81 / 4$ & $77 / 8$ & 7 & & قتحة الرجل \\
\hline 6 & $53 / 4$ & $51 / 2$ & & رب أسورة قتحة الرجل \\
\hline 2 & 2 & 2 & & ارتفاع رب أسورة قتحة الرجل \\
\hline 20 & 18 & 16 & & الخياطة الداخلية \\
\hline 1 & 1 & 1 & أسفل الكمر & 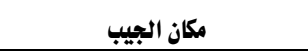 \\
\hline $51 / 2$ & $51 / 2$ & $51 / 2$ & & طول الجيب \\
\hline $31 / 2$ & $31 / 2$ & $31 / 2$ & & ارتفاع القصة (الأمامية و الخلفية ) \\
\hline $5 / 8$ & $5 / 8$ & $5 / 8$ & ل للكل & عرض الشريط \\
\hline 1 & 1 & 1 & من خط الجنب & مكان الشريط \\
\hline $41 / 2$ & $41 / 2$ & $41 / 2$ & أسفل خياطة القصة الأمامية & مكان التصمييه يسار الأمام \\
\hline $1 / 2$ & $1 / 2$ & $1 / 2$ & أسفل الكمر & مكان التصميي \\
\hline
\end{tabular}


تقرير التقشيق للبنطلون الأول مقاس (M-L-XL) عرض •rا سم

\begin{tabular}{|c|c|c|}
\hline \multicolumn{3}{|c|}{ Order Info } \\
\hline اسم العميل & دكتور إيهاب & اسم المستخدم \\
\hline مقاسات التعشيق & $\mathrm{M} 1: \mathrm{M}(\mathrm{x} 1) ; \mathrm{L}(\mathrm{x} 1) ; \mathrm{XL}(\mathrm{x} 1)$ & |التاريخ / الوقت \\
\hline اسم الملف & & \\
\hline
\end{tabular}

\begin{tabular}{|c|c|c|c|c|}
\hline \multicolumn{5}{|c|}{ Marker info } \\
\hline عرض الماركر & 120 & $\mathrm{Cm}$ & علد النمازج & 1 \\
\hline طول الماركر & 2.84 & M & علد القطع & 3 \\
\hline \multirow{2}{*}{ كفاءة التعشيق } & \multirow{2}{*}{\multicolumn{2}{|c|}{$89.27 \%$}} & إجمالي علد الأجزاء & 48 \\
\hline & & & عدد الأجزاء المشقة & 48 \\
\hline
\end{tabular}

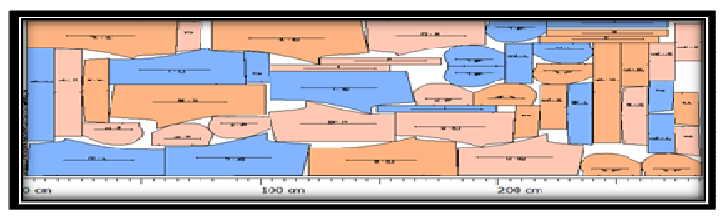

\begin{tabular}{|c|c|c|}
\hline وزن وحدة القياس & 220 & $\mathrm{G} / \mathrm{m}^{2}$ \\
\hline إجماني وزن القماش & 0.75 & KG \\
\hline الوزن المستخدم & 0.67 & KG \\
\hline وزن الهالك & 0.08 & KG \\
\hline
\end{tabular}

تقرير التعشيق للبنطلون الأول مقاس (M-L-XL) عرض •ـا سم

\begin{tabular}{|c|c|c|}
\hline \multicolumn{3}{|c|}{ Order Info } \\
\hline اسم العميل & دكتور إيهاب & اسم المستخلم \\
\hline مقاسات التشيق & $\mathrm{M} 1: \mathrm{M}(\mathrm{x} 1) ; \mathrm{L}(\mathrm{x} 1) ; \mathrm{XL}(\mathrm{x} 1)$ & التاريخ / الوقت | \\
\hline اسم الملف & Tord & \\
\hline & & \\
\hline
\end{tabular}

\begin{tabular}{|c|c|c|c|}
\hline \multicolumn{4}{|c|}{ Marker info } \\
\hline عرض الماركر & $140 \mathrm{~cm}$ & عدد النمازج & 1 \\
\hline طول الماركر & $2.44 \mathrm{~m}$ & علد القطع & 3 \\
\hline \multirow[t]{2}{*}{ كفاءة التقشيق } & \multirow{2}{*}{$88.94 \%$} & | إجمالي عدد الأجزاء & 48 \\
\hline & & |عددد الأجزاء المعشقة & 48 \\
\hline
\end{tabular}

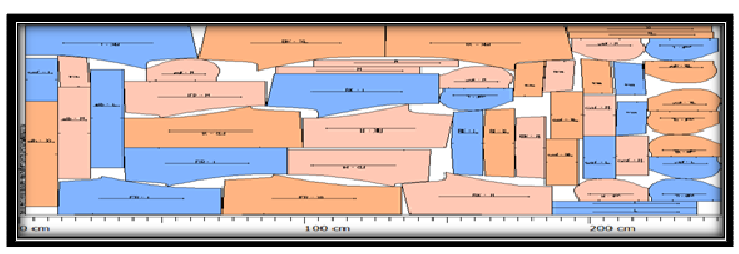

\begin{tabular}{|c|c|c|}
\hline وزن وحدة القياس & 220 & $\mathrm{G} / \mathrm{m}^{2}$ \\
\hline إجمالي وزن القماش & 0.75 & KG \\
\hline الوزن المستخدم & 0.67 & $\mathrm{KG}$ \\
\hline وزن الهالك & 0.08 & $\mathrm{KG}$ \\
\hline
\end{tabular}

تقرير التعشيق للبنطلون الأول مقاس (M-L-XL)عرض • 17 سم

\begin{tabular}{|c|c|c|}
\hline \multicolumn{3}{|c|}{ Order Info } \\
\hline اسم العميل & دكتور إيهاب & اسم المستخدم \\
\hline مقاسات التعشيق & $\mathrm{M} 1: \mathrm{M}(\mathrm{x} 1) ; \mathrm{L}(\mathrm{x} 1) ; \mathrm{XL}(\mathrm{x} 1)$ & التاريخ / الوقت \\
\hline اسم الملف & (10. ro..4ord & \\
\hline
\end{tabular}

\begin{tabular}{|c|c|c|c|}
\hline \multicolumn{4}{|c|}{ Marker info } \\
\hline عرض الماركر & $160 \mathrm{~cm}$ & عدد النمازج & 1 \\
\hline طول الماركر & \begin{tabular}{|l|l}
2.14 & $\mathrm{~m}$ \\
\end{tabular} & علد القطع & 3 \\
\hline كفاءة التششت & $8863 \%$ & إجمالي عدد الأجزاي & 48 \\
\hline & & علدد الأجزاء المشقة & 48 \\
\hline
\end{tabular}

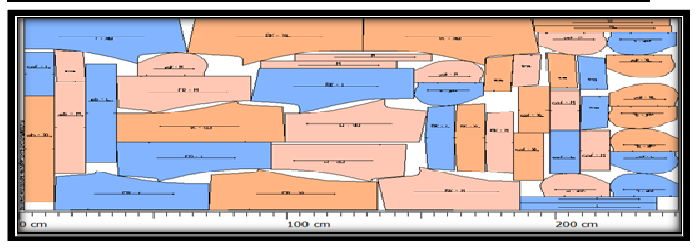

\begin{tabular}{|c|c|c|}
\hline وزن وحدة القياس & 220 & $\mathrm{G} / \mathrm{m} 2$ \\
\hline إجمالي وزن القماش & 0.75 & KG \\
\hline الوزن المستخدم & 0.67 & $\mathrm{KG}$ \\
\hline وزن الهالك & 0.09 & KG \\
\hline
\end{tabular}

شكل رقم(ץ) يوضح تقرير التعشيق للبنطلون الأول مقاس(M-L-XL) بثلاث عروض مختلفة 


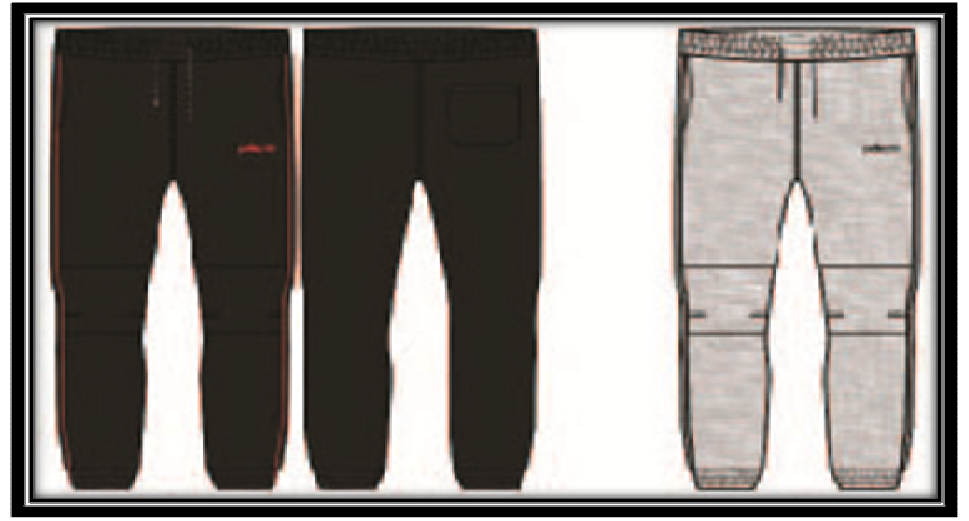

شكل رقم(r) يوضح تصميم البنطلون الثانى مقاس (r-L-XL)

جدول رقم(Y) يوضح توصيف العميل لمقاسات البنطلون الثانى مقاس (M-L-XL) بالبوصيه

\begin{tabular}{|c|c|c|c|c|c|}
\hline $\mathrm{XL}$ & $\mathrm{L}$ & M & سماحيات ـ & سماحيات + & المواصفات \\
\hline $291 / 2$ & $281 / 2$ & $261 / 2$ & $1 / 2$ & $1 / 2$ & الوسط بدون شد دائري \\
\hline $361 / 2$ & 35 & 32 & $1 / 2$ & $1 / 2$ & الوسط مشدود دائرى \\
\hline $3 / 4$ & $3 / 4$ & $3 / 4$ & $1 / 4$ & $1 / 4$ & من نصف الاهام عند منتصف الخلف \\
\hline $13 / 4$ & $13 / 4$ & $13 / 4$ & $1 / 4$ & $1 / 4$ & ارتفاع الكمر \\
\hline $131 / 8$ & 12 & $111 / 4$ & $1 / 4$ & $1 / 4$ & الحجر الامامي \\
\hline $157 / 8$ & $143 / 4$ & 14 & $1 / 4$ & $1 / 4$ & الحجر الخلفي \\
\hline 3 & 3 & 3 & $1 / 4$ & $1 / 4$ & مكان الأجناب \\
\hline $401 / 2$ & $371 / 2$ & $341 / 2$ & $1 / 4$ & $1 / 4$ & مقاس الأجناب \\
\hline $231 / 4$ & $221 / 4$ & $201 / 4$ & $1 / 4$ & $1 / 4$ & عرض الفخذ \\
\hline 13 & $121 / 2$ & 12 & $1 / 4$ & $1 / 4$ & مكان الركبة \\
\hline $161 / 4$ & $151 / 2$ & 14 & $1 / 4$ & $1 / 4$ & عرض الركبة \\
\hline $111 / 8$ & $101 / 2$ & $91 / 4$ & $1 / 4$ & $1 / 4$ & قتحة الرجل \\
\hline $13 / 4$ & $13 / 4$ & $13 / 4$ & $1 / 8$ & $1 / 8$ & أرتفاع الاسورة \\
\hline $301 / 2$ & 29 & 26 & $1 / 4$ & $1 / 4$ & طول الداخلي للرجل \\
\hline 35 & 34 & 32 & $3 / 8$ & $3 / 8$ & طول الكردون \\
\hline $41 / 4$ & $41 / 4$ & 4 & $1 / 8$ & $1 / 8$ & عرض جيب الظهر \\
\hline $1 / 2$ & $1 / 2$ & $1 / 2$ & $1 / 8$ & $1 / 8$ & إرتفاع جيب الظهر \\
\hline 2 & 2 & 2 & $1 / 8$ & $1 / 8$ & مكان الجيب أسفل الكمر \\
\hline $51 / 4$ & 5 & 5 & $1 / 8$ & $1 / 8$ & طول جنب الأمام \\
\hline $11 / 4$ & $11 / 4$ & $11 / 4$ & $1 / 4$ & $1 / 4$ & قتحة العروة \\
\hline
\end{tabular}


تقرير التفشيق للبنطلون الثانى مقاس (M-LXL عرض • ما سم

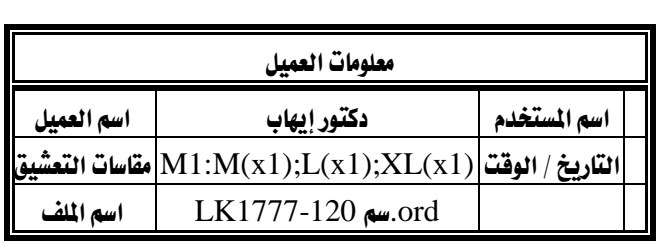

\begin{tabular}{|c|c|c|c|c|}
\hline \multicolumn{5}{|c|}{ معلومات التقشيق } \\
\hline عرضالماركر & 120 & $\mathrm{~cm}$ & علد النمازج & 1 \\
\hline 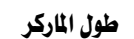 & 3.24 & $\mathrm{~m}$ & علد القطع & 3 \\
\hline كفاءة التشيق & \multirow{2}{*}{\multicolumn{2}{|c|}{$85.79 \%$}} & إجماني علد الأجزاء & 36 \\
\hline & & & عدد الأجزاء المشقة & 36 \\
\hline
\end{tabular}

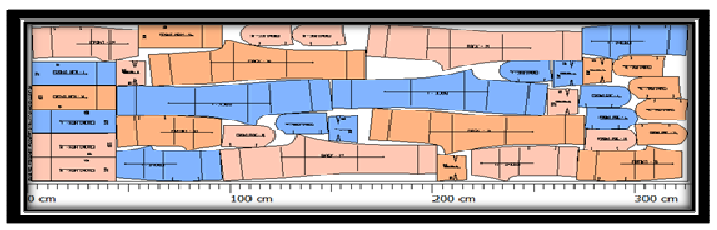

\begin{tabular}{|c|c|c|}
\hline وزن وحدة القياس & 220 & $\mathrm{G} / \mathrm{m} 2$ \\
\hline إجمالي وزن القماش & 0.86 & $\mathrm{KG}$ \\
\hline الوزن المتخدم & 0.73 & $\mathrm{KG}$ \\
\hline وزن الهالك & 0.12 & $\mathrm{KG}$ \\
\hline
\end{tabular}

تقرير التعشيق للبنطلون الثانى مقاس (M-LXL ) عرض •کا سم

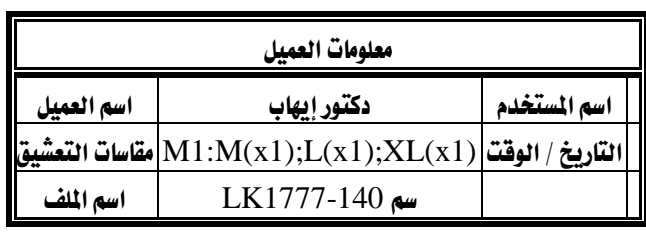

\begin{tabular}{|c|c|c|c|}
\hline \multicolumn{4}{|c|}{ معلومات التعشيق } \\
\hline عرض الماركر & $140 \mathrm{~cm}$ & عدد النمازج & 1 \\
\hline طول الماركر & $2.78 \mathrm{M}$ & علد القطع & 3 \\
\hline \multirow[t]{2}{*}{ كفاءة التقشيق } & \multirow{2}{*}{$85.92 \%$} & إجمالي علد الأجزاء & 36 \\
\hline & & عدد الأجزاء المعشقه & 36 \\
\hline
\end{tabular}

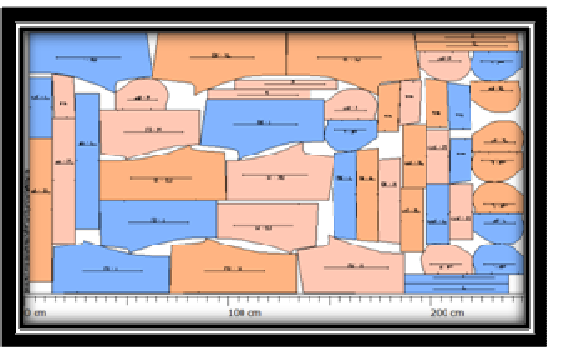

\begin{tabular}{|c|c|c|}
\hline وزن وحدة القياس & 220 & $\mathrm{G} / \mathrm{m} 2$ \\
\hline إجمالي وزن القماش & 0.86 & KG \\
\hline الوزن المستخدم & 0.73 & KG \\
\hline وزن الهالك & 0.12 & KG \\
\hline
\end{tabular}

تقرير التقشيق للبنطلون الثانى مقاس (M-L_XL ) عرض •17 سم لـ

\begin{tabular}{|c|c|c|}
\hline \multicolumn{3}{|c|}{ معلومات العميل } \\
\hline 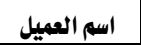 & دكتور إيهاب & 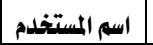 \\
\hline مقاسات التقشيق & $\mathrm{M} 1: \mathrm{M}(\mathrm{x} 1) ; \mathrm{L}(\mathrm{x} 1) ; \mathrm{XL}(\mathrm{x} 1)$ & | التاريخ / الوقت \\
\hline اسم الملف ل الف & LK1777-160سمصard & \\
\hline
\end{tabular}

\begin{tabular}{|c|c|c|c|}
\hline \multicolumn{4}{|c|}{ معلومات التعشيق } \\
\hline عرض الماركر & $160 \mathrm{~cm}$ & علد النمازج & \\
\hline طول الماركر & \begin{tabular}{|l|l}
2.42 & $\mathrm{M}$ \\
\end{tabular} & علد القطع & 3 \\
\hline \multirow[t]{2}{*}{ كفاءة التششيق } & \multirow{2}{*}{$86.27 \%$} & ] [إجمالي عدد الأجزاء & \\
\hline & & ? عددد الأجزاء المشقة & 36 \\
\hline
\end{tabular}

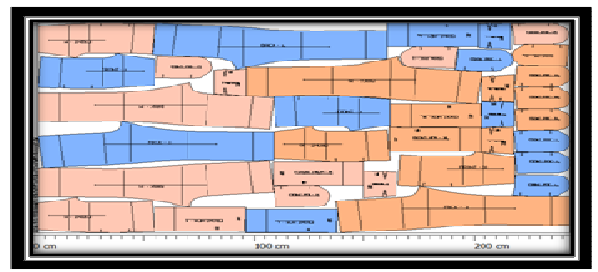

\begin{tabular}{|c|c|c|}
\hline وزن وحدة القياس & 220 & $\mathrm{G} / \mathrm{m} 2$ \\
\hline إجمالي وزن القماش & 0.85 & KG \\
\hline الوزن الستخلدم & 0.73 & KG \\
\hline وزن الهالك & 0.12 & KG \\
\hline
\end{tabular}

شكل رقم(ع) يوضح تقرير التعشيق للبنطلون الثاني مقاس (M-L _ _XL ) بثلاث عروض مختلفة 


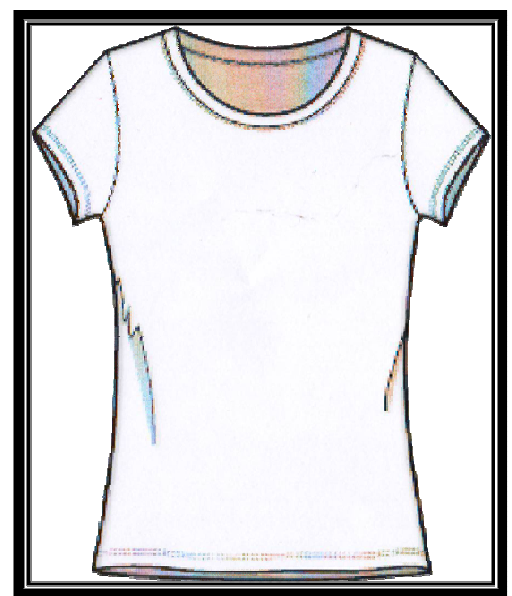

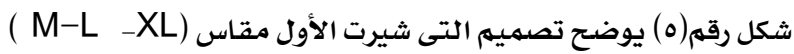
جدول رقم(r) يوضح توصيف العميل لمقاسات التى شيرت الأول مقاس (M-L _XL ) بالبوصنه

\begin{tabular}{|c|c|c|c|c|}
\hline $\mathrm{XL}$ & $\mathrm{L}$ & M & تفاصيل التوصيف & التوصيف \\
\hline 23 & 22 & 21 & من أعلي نقطة في الكتف إلي الزيل & الطول الكلي \\
\hline $151 / 2$ & 15 & $141 / 2$ & ا بوصة أسفل حردة الإبط & 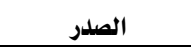 \\
\hline 14 & $131 / 2$ & 13 & & عرض الكتف \\
\hline 13 & $121 / 2$ & 12 & منصف قتحة الأبط & عرض الصدر \\
\hline $131 / 2$ & 13 & $121 / 2$ & منصف قتحة الأبط & عرض الظهر \\
\hline 1 & $11 / 4$ & 1 & & ميل الكتف \\
\hline 15 & $141 / 2$ & 14 & & الوسط الو \\
\hline 17 & 16 & 15 & & الذيل مرتاح \\
\hline $75 / 8$ & $71 / 4$ & $67 / 8$ & & حردة الأبط مستقيم \\
\hline 12 & $111 / 2$ & 11 & & أقل أتساع للرقبة \\
\hline $1 / 2$ & 13 & $121 / 2$ & & طول الوسط \\
\hline $55 / 8$ & $51 / 4$ & $47 / 8$ & من قتحة الابط و حتي النهاية & طول الكم \\
\hline $51 / 2$ & $51 / 4$ & 5 & & قتحة الكم \\
\hline $63 / 4$ & $61 / 2$ & $61 / 4$ & من جهة الحياكة الداخلية & قتحة الرقبة \\
\hline $31 / 4$ & 3 & $23 / 4$ & من أعلي منطقة في الكتف إلي خط الحياكة & سقوط الرقبة الامامي \\
\hline 1 & 1 & 1 & من أعلي منطقة في الكتف إلي خط الحياكة & سقوط الرقبة الخلفي \\
\hline 1 & $13 / 4$ & 1 & من خط حياكة الرقبة & مكان الطباعة \\
\hline
\end{tabular}


تقرير التعشيق للقى شيرت الأول مقاس (M-LXL ) عرض •^ سم

\begin{tabular}{|c|c|c|}
\hline \multicolumn{3}{|c|}{ معلومات العميل } \\
\hline اسم العميل & دكتور إيهاب & اسم المستخدم \\
\hline مقاسات & $\begin{array}{c}\mathrm{M}: \\
(\mathrm{x} 1) ; \mathrm{L}(\mathrm{x} 1) ; \mathrm{XL}(\mathrm{x} 1)\end{array}$ & التاريخ / الوقت \\
\hline اسم الملف & & \\
\hline
\end{tabular}

\begin{tabular}{|c|c|c|c|c|}
\hline \multicolumn{5}{|c|}{ معلومات التعشيق } \\
\hline عرض الماركر & 80 & $\mathrm{Cm}$ & عدد النهازج & 1 \\
\hline طول الماركر & 4.88 & M & علد القطع ع ع & 3 \\
\hline كفاءة التعشيق & \multirow{2}{*}{\multicolumn{2}{|c|}{$73.18 \%$}} & إجمالي علد الأجزاء & 14 \\
\hline & & & عدد الأجزاء المعشقة & 14 \\
\hline
\end{tabular}

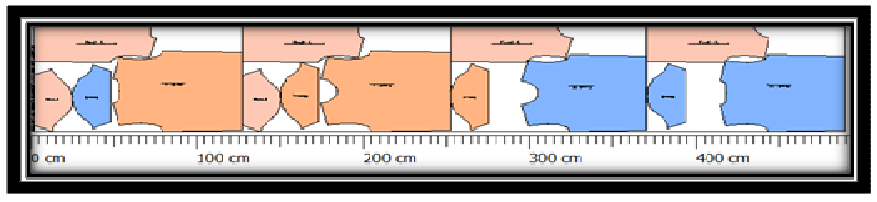

\begin{tabular}{|c|c|c|}
\hline وزن وحدة القياس & 180 & $\mathrm{G} / \mathrm{m} 2$ \\
\hline إجمالي وزن القماش & 0.7 & $\mathrm{KG}$ \\
\hline الوزن المستخدم & 0.51 & $\mathrm{KG}$ \\
\hline وزن الهالك & 0.19 & $\mathrm{KC}$ \\
\hline
\end{tabular}

تقرير التعشيق للقى شيرت الأول مقاس (M-LXL ) عرض •9 سم

\begin{tabular}{|c|c|c|}
\hline \multicolumn{3}{|c|}{ معلومات العميل } \\
\hline اسم العميل & دكتور إيهاب & | اسم المستخدم \\
\hline مقاسات التعشيق & $\mathrm{M}:(\mathrm{x} 1) ; \mathrm{L}(\mathrm{x} 1) ; \mathrm{XL}(\mathrm{x} 1)$ & | التاريخ / الوقت \\
\hline اسم الملف & . & \\
\hline
\end{tabular}

\begin{tabular}{|c|c|c|c|}
\hline \multicolumn{4}{|c|}{ معلومات التعشيق } \\
\hline عرض الماركر & $90 \mathrm{~cm}$ & علد النمازج & 1 \\
\hline طول الماركر & \begin{tabular}{l|l}
3.80 & $\mathrm{M}$ \\
\end{tabular} & علد القطع & 3 \\
\hline \multirow{2}{*}{ كفاءة التعشيق } & \multirow{2}{*}{$83.53 \%$} & إجمالي علد الأجزاء & 14 \\
\hline & & عددد الأجزاء المعشقة & 14 \\
\hline
\end{tabular}

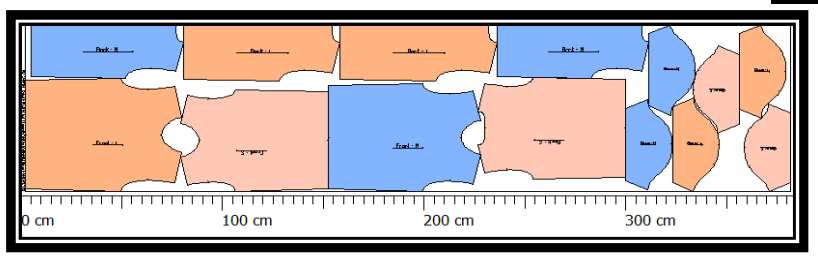

\begin{tabular}{|c|c|c|}
\hline وزن وحدة القياس & 180 & $\mathrm{G} / \mathrm{m} 2$ \\
\hline إجمالي وزن القماش & 0.82 & KG \\
\hline الوزن المستخدم & 0.51 & KG \\
\hline وزن الهالك & 0.23 & KG \\
\hline
\end{tabular}

تقرير التقشيق للى شيرت الأول مقاس (M-LXL ) عرض •ـا سم

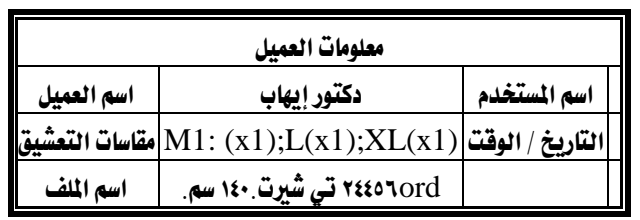

\begin{tabular}{|c|c|c|c|c|}
\hline \multicolumn{5}{|c|}{ معلومات التعشيق } \\
\hline عرض الماركر & 140 & $\mathrm{~cm}$ & عدد النمازج & 1 \\
\hline طول الماركر & 2.69 & $\mathrm{~m}$ & عدد القطع & 3 \\
\hline كفاءة التشيق & \multirow{2}{*}{\multicolumn{2}{|c|}{$75.83 \%$}} & إجمالي عدد الأجزاء & 14 \\
\hline & & & عددد الأجزاء المعشقة & 12 \\
\hline
\end{tabular}

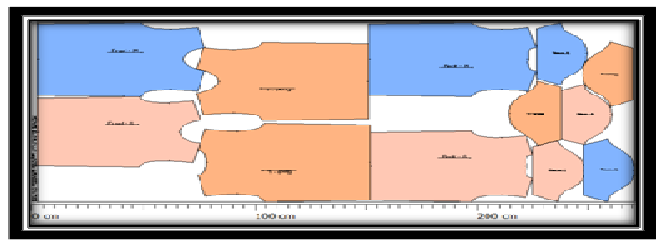

\begin{tabular}{|c|c|c|}
\hline وزن وحلدة القياس & 180 & $\mathrm{G} / \mathrm{m} 2$ \\
\hline جمالي وزن القماثر & 0.68 & KG \\
\hline الوزن المستخلم & 0.51 & KG \\
\hline وزن الهالك & 0.16 & KG \\
\hline
\end{tabular}

شكل رقم (ج) يوضح تقرير التعشيق للتى شيرت الأول مقاس (M-L - Cيثلاث عروض مختلفه 


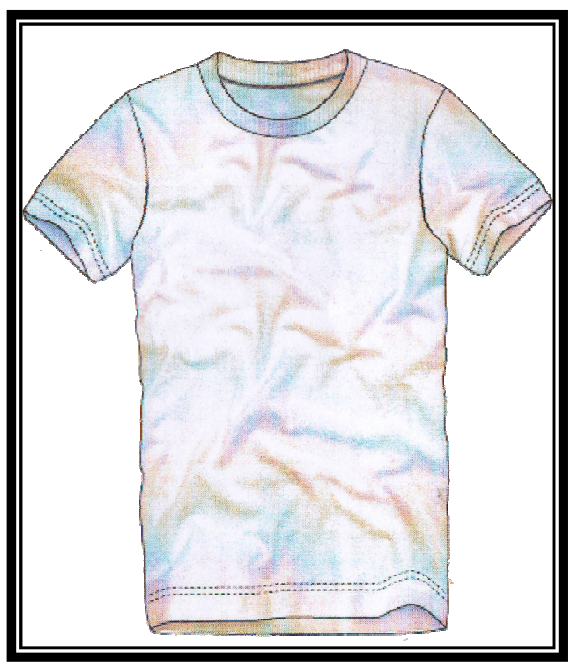

شكل رقم(V) يوضح تصميم التى شيرت الثانى مقاس (M-L _ -XL)

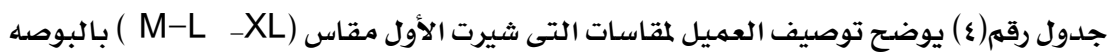

\begin{tabular}{|c|c|c|c|c|}
\hline $\mathrm{XL}$ & $\mathrm{L}$ & $\mathrm{M}$ & تفاصيل التوصيف & التوصيف \\
\hline 26 & 25 & 24 & من أعلي منطقة في الكتف إلي الزيل & الطول الكلي \\
\hline 18 & $171 / 2$ & 17 & ا بوصة أسفل حردة الأبط & الصلدر \\
\hline $151 / 2$ & 15 & $141 / 2$ & & عرض الكتف \\
\hline $141 / 2$ & 14 & $131 / 2$ & منتصف قتحة حردة الأبط & عرض الصدر \\
\hline 15 & $141 / 2$ & 14 & منتصف قتحة حردة الأبط & عرض الظهر \\
\hline $11 / 4$ & $11 / 4$ & $11 / 4$ & & 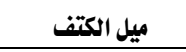 \\
\hline $181 / 2$ & $171 / 2$ & $161 / 2$ & & الذيل مرتاح \\
\hline $75 / 8$ & $71 / 4$ & $77 / 8$ & & حردة الأبط مستقيم \\
\hline $71 / 4$ & $71 / 4$ & $71 / 4$ & من حردة الإبط إلي النهاية & طول الكم \\
\hline $75 / 8$ & $61 / 4$ & $77 / 8$ & & قتحة الكم \\
\hline $73 / 4$ & $71 / 2$ & $71 / 4$ & من الحياكة إلي الحياكة & قتحة الرقبة \\
\hline $31 / 2$ & $31 / 4$ & 3 & من أعلي منطقة في الكتف إلي خط الحياكة & 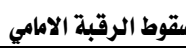 \\
\hline 1 & 1 & 1 & من أعلي منطقة في الكتف إلي خط الحياكة & ت بقوط الرقبة الخلفي \\
\hline 12 & $111 / 2$ & 11 & & أقل أتساع للرقبة \\
\hline $3 / 4$ & $3 / 4$ & $3 / 4$ & & أرتفاع الرب \\
\hline
\end{tabular}


تقرير التعشيق للقى شيرت الثانى مقاس (M-L_XL ) عرض •م سم

\begin{tabular}{|c|c|c|}
\hline \multicolumn{3}{|c|}{ معلومات العميل } \\
\hline اسم العميل & دكتور إيهاب & 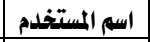 \\
\hline | مقاسات التعشيق| & $\mathrm{M} 1: \mathrm{M}(\mathrm{x} 1) ; \mathrm{L}(\mathrm{x} 1) ; \mathrm{XL}(\mathrm{x} 1)$ & | التاريخ / الوقت \\
\hline اسم الملف & تي شيرت كلفنـ •A سم. & \\
\hline
\end{tabular}

\begin{tabular}{|c|c|c|c|c|}
\hline \multicolumn{5}{|c|}{ معلومات التعشيق } \\
\hline عرض الماركر & 80 & $\mathrm{~cm}$ & عدد النمازج & 1 \\
\hline طول الماركر & 5.71 & $\mathrm{~m}$ & عدد القطع & 3 \\
\hline كفاءة التعشيق & \multirow{2}{*}{\multicolumn{2}{|c|}{$72.11 \%$}} & إجماني علد الأجزاء & 15 \\
\hline & & & عدد الأجزاء المشقة & 15 \\
\hline
\end{tabular}

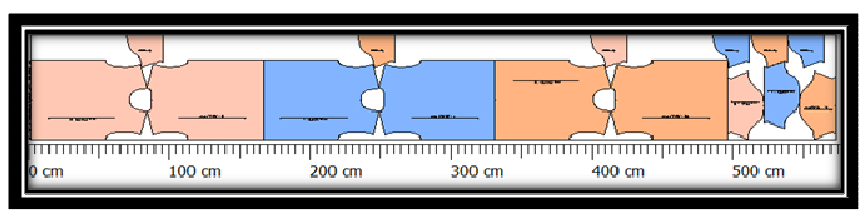

\begin{tabular}{|c|c|c|}
\hline وزن وحدة القياس & 180 & $\mathrm{G} / \mathrm{m} 2$ \\
\hline جمالي وزن القماثر & 0.82 & $\mathrm{KG}$ \\
\hline الوزن المستخدم & 0.59 & $\mathrm{KG}$ \\
\hline وزن الهالك & 0.23 & KG \\
\hline
\end{tabular}

تقرير التعشيق للقى شيرت الثانى مقاس (M-L_XL ) عرض •9 سم

\begin{tabular}{|c|c|c|}
\hline \multicolumn{3}{|c|}{ معلومات العميل } \\
\hline اسم العميل & دكتور إيهاب & 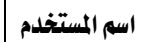 \\
\hline مقاسات التعشيق & $\mathrm{M} 1: \mathrm{M}(\mathrm{x} 1) ; \mathrm{L}(\mathrm{x} 1) ; \mathrm{XL}(\mathrm{x} 1)$ & | التاريخ / الوقت \\
\hline اسم الملف & متي شيرت كلفنـ •qسم. & \\
\hline
\end{tabular}

\begin{tabular}{|c|c|c|c|c|}
\hline \multicolumn{5}{|c|}{ معلومات التعشيق } \\
\hline عرض الماركر & 90 & $\mathrm{Cm}$ & عدد النمازج & 1 \\
\hline طول الماركر & \multicolumn{2}{|c|}{\begin{tabular}{|l|l}
4.33 & $\mathrm{M}$ \\
\end{tabular}} & عدد القطع & 3 \\
\hline \multirow{2}{*}{ كفاءة التعشيق } & \multirow{2}{*}{\multicolumn{2}{|c|}{$84.88 \%$}} & إجمالي علد الأجزاء & 16 \\
\hline & & & عددد الأجزاء المعشقة & 16 \\
\hline
\end{tabular}

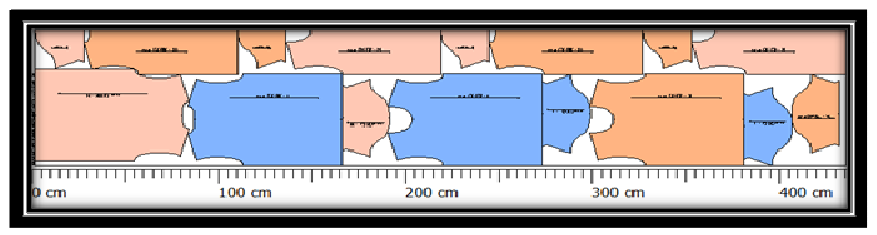

\begin{tabular}{|c|c|c|}
\hline وزن وحدة القياس & 180 & $\mathrm{G} / \mathrm{m} 2$ \\
\hline إجمالي وزن القماش & 0.7 & KG \\
\hline الوزن المستخدم & 0.59 & $\mathrm{KG}$ \\
\hline وزن الهالك & 0.11 & KG \\
\hline
\end{tabular}

تقرير التعشيق للقى شيرت الثانى مقاس (M-L_XL ) عرض •کـا سم
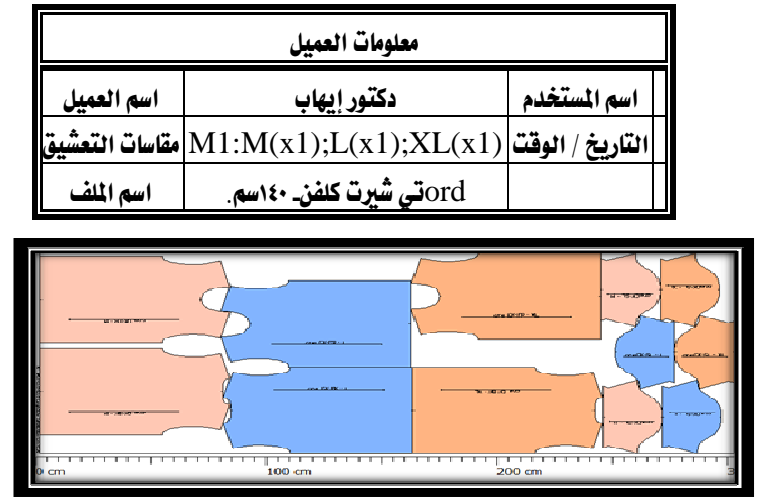

شكل رقم(^) يوضح تقرير التعشيق للتى شيرت الثانى مقاس (M-L - C بثلاث عروض مختلفه 


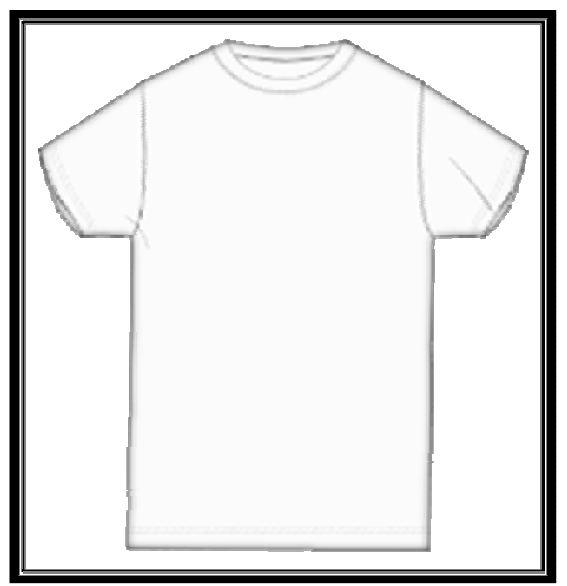

شكل رقم(ه) يوضح تصميم التى شيرت الأول بدون قصات مقاس (S- M-L)

جدول رقم(ج) يوضح توصيف العميل لمقاسات التى شيرت بدون قصات مقاس (S- M-L) بالبوصيه

\begin{tabular}{|c|c|c|c|c|c|}
\hline $\mathrm{L}$ & $\mathrm{M}$ & $\mathrm{S}$ & السماحيات (+) & السماحيات (-) & التوصيف \\
\hline $181 / 2$ & $161 / 2$ & $141 / 2$ & $3 / 8$ & $3 / 8$ & عرض أعلي الصلد ه بوصة من أعلي نقطة من الكتف \\
\hline 23 & 21 & 19 & $1 / 2$ & $1 / 2$ & آ/ الصلد - ا بوصة أسفل حردة الأبط \\
\hline 23 & 21 & 19 & $1 / 2$ & $1 / 2$ & 1/ إقتحة الزيل \\
\hline $3 / 4$ & $3 / 4$ & $3 / 4$ & $1 / 8$ & $1 / 8$ & أرتفاع الأورلية \\
\hline $83 / 8$ & $77 / 8$ & $73 / 8$ & $1 / 4$ & $1 / 4$ & طول الكم من الكتف \\
\hline $47 / 8$ & $43 / 8$ & $37 / 8$ & $1 / 4$ & $1 / 4$ & طول الكم الداخلي \\
\hline $87 / 8$ & $83 / 8$ & $77 / 8$ & $1 / 4$ & $1 / 4$ & عرض العضلة \\
\hline $75 / 8$ & $71 / 4$ & $67 / 8$ & $1 / 4$ & $1 / 4$ & قتحة الكم \\
\hline 20 & 18 & 16 & $3 / 8$ & $3 / 8$ & عرض الأكتاف \\
\hline $15 / 8$ & $15 / 8$ & $15 / 8$ & $1 / 4$ & $1 / 4$ & ميل الكتف من أعلي نقطة \\
\hline $1 / 2$ & $1 / 2$ & $1 / 2$ & $1 / 4$ & $1 / 4$ & خط الكتف الأمامي \\
\hline $181 / 2$ & $161 / 2$ & $141 / 2$ & $3 / 8$ & $3 / 8$ & عرض الظهر ه بوصة من أعلي نقطة من الكتف \\
\hline $111 / 2$ & 11 & $101 / 2$ & $1 / 4$ & $1 / 4$ & عمق الابط من الكتف \\
\hline 10 & $91 / 2$ & 9 & $1 / 4$ & $1 / 4$ & طول حردة الأبط مستقيمة \\
\hline $71 / 4$ & 7 & $63 / 4$ & $1 / 4$ & $1 / 4$ & قتحة الرقبة \\
\hline $43 / 4$ & $45 / 8$ & $41 / 2$ & $1 / 4$ & $1 / 4$ & قتحة الرقبة الامامية \\
\hline $11 / 8$ & 1 & 1 & $1 / 4$ & $1 / 4$ & عمق قتحة الرقبة الخخلفية \\
\hline $3 / 4$ & $3 / 4$ & $3 / 4$ & $1 / 8$ & $1 / 8$ & أرتفاع الريب \\
\hline 31 & 30 & 29 & $1 / 2$ & $1 / 2$ & الطول الكلي \\
\hline
\end{tabular}


تقرير التعشيق للقى شيرت بلدون قصات مقاس (S- M-L) عرض •^ سم

\begin{tabular}{|c|c|c|c|c|c|c|c|}
\hline \multirow{2}{*}{\multicolumn{3}{|c|}{ معلومات العميل }} & \multicolumn{5}{|c|}{ معلومات التصشيق } \\
\hline & & & عرض الماركر & 80 & $\mathrm{~cm}$ & عدد النمازج & 1 \\
\hline اسم العميل & دكتور إيهاب & | اسم المستخدم & طول الماركر & 5.65 & $\mathrm{~m}$ & علد القطع & 3 \\
\hline مقاسات التقشيق & $\mathrm{M} 1: \mathrm{S}(\mathrm{x} 1) ; \mathrm{M}(\mathrm{x} 1) ; \mathrm{L}(\mathrm{x} 1)$ & |التاريخ / الوقت & كفاءة التقشيق & & & إجماني علد الأجزاء & 15 \\
\hline اسم الملف ل الف & CK under CRW سم $80.0 r d$ & & & 75.12 & & علد الأجزاء المشقة & 15 \\
\hline
\end{tabular}

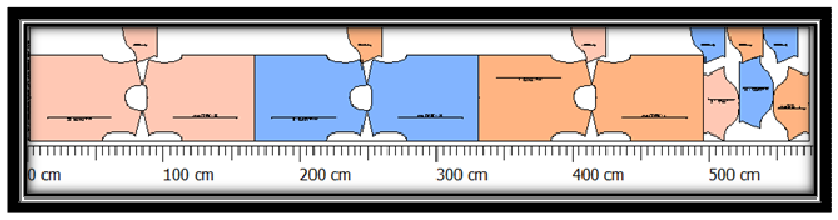

\begin{tabular}{|c|c|c|}
\hline وزن وحدة القياس & 180 & $\mathrm{G} / \mathrm{m} 2$ \\
\hline إجمالي وزن القماش & 0.82 & KG \\
\hline الوزن المستخدم & 0.59 & KG \\
\hline وزن الهالك & 0.23 & KG \\
\hline
\end{tabular}

تقرير التصشيق للقى شيرت بلدون قصات مقاس (S- M-L) عرض •9 سم

\begin{tabular}{|c|c|c|}
\hline \multicolumn{3}{|c|}{ معلومات العميل } \\
\hline 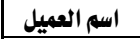 & دكتور إيهاب & 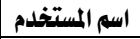 \\
\hline مقاسات التعشيق & M1:S(x1);M(x1);L(x1) & التاريخ / الوقت \\
\hline 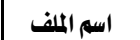 & CK under CRW سم900.ord & \\
\hline
\end{tabular}

\begin{tabular}{|c|c|c|c|}
\hline \multicolumn{4}{|c|}{ معلومات التعشيق } \\
\hline عرض الماركر & $90 \mathrm{~cm}$ & علد النمازج & 1 \\
\hline طول الماركر & \begin{tabular}{l|l}
4.27 & $\mathrm{~m}$ \\
\end{tabular} & علد القطع & 3 \\
\hline \multirow{2}{*}{ كل كفاءة التشيق } & \multirow{2}{*}{$85.12 \%$} & إجمالي عدد الأجزاء & 16 \\
\hline & & عددد الأجزاء المعشقة & 16 \\
\hline
\end{tabular}

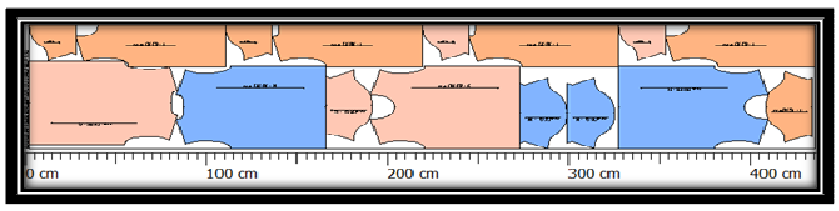

\begin{tabular}{|c|c|c|}
\hline وزن وحدة القياس & 180 & $\mathrm{G} / \mathrm{m} 2$ \\
\hline إجمالي وزن القماش & 0.7 & KG \\
\hline الوزن المستخدم & 0.59 & $\mathrm{KG}$ \\
\hline وزن الهالك & 0.11 & KG \\
\hline
\end{tabular}

تقرير التعشيق للى شيرت بلدوذ قصات مقاس (S- M-L) عرض •10 سم
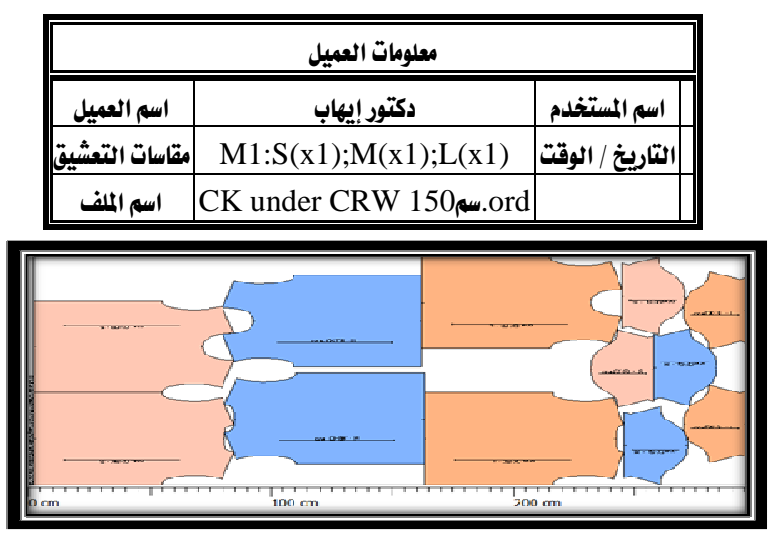

شكل رقم ( 1) يوضح تقرير التعشيق للتى شيرت بدون قصات مقاس (S- M-L) بثلاث عروض مختلفه 


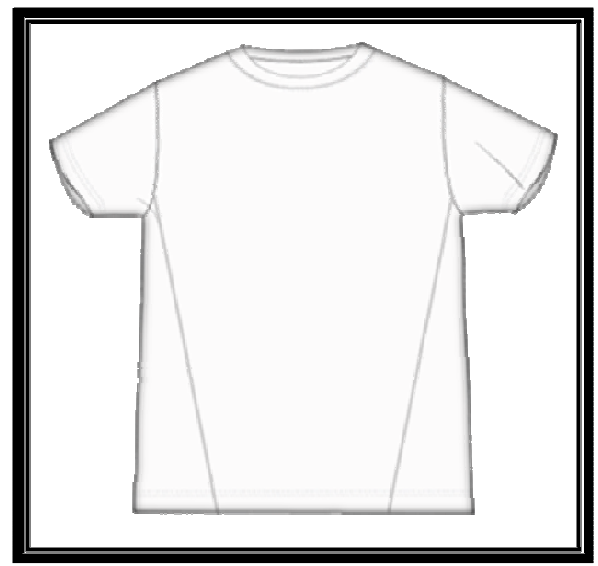

شكل رقم(11) يوضح تصميم التى شيرت الثانى بقصات مقاس (S- M-L)

جدول رقم(V) يوضح توصيف العميل لمقاسات التى شيرت بقصات مقاس (S- M-L) بالبوصه

\begin{tabular}{|c|c|c|c|c|c|}
\hline $\mathrm{L}$ & $\mathrm{M}$ & $\mathrm{S}$ & السماحيات (+) & السماحيات (-) & التوصيف \\
\hline $181 / 2$ & $161 / 2$ & $141 / 2$ & $3 / 8$ & $3 / 8$ & مرض أعلي الصدر ه بوصة من أعلي نقطة من الكتف \\
\hline 23 & 21 & 19 & $1 / 2$ & $1 / 2$ & إ/ الصدر - ا بوصة أسفل حردة الأبط \\
\hline 23 & 21 & 19 & $1 / 2$ & $1 / 2$ & ب/l ب قتحة الزيل \\
\hline $3 / 4$ & $3 / 4$ & $3 / 4$ & $1 / 8$ & $1 / 8$ & أرتفاع الأورلية \\
\hline $83 / 8$ & $77 / 8$ & $73 / 8$ & $1 / 4$ & $1 / 4$ & 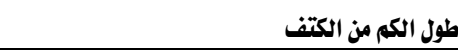 \\
\hline $47 / 8$ & $43 / 8$ & $37 / 8$ & $1 / 4$ & $1 / 4$ & 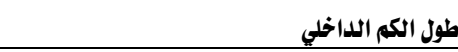 \\
\hline $87 / 8$ & $83 / 8$ & $77 / 8$ & $1 / 4$ & $1 / 4$ & عرض العضلة \\
\hline $75 / 8$ & $71 / 4$ & $67 / 8$ & $1 / 4$ & $1 / 4$ & قتحة الكم \\
\hline 20 & 18 & 16 & $3 / 8$ & $3 / 8$ & عرض الأكتاف \\
\hline $15 / 8$ & $15 / 8$ & $15 / 8$ & $1 / 4$ & $1 / 4$ & ميل الكتف من أعلي نقطة \\
\hline $1 / 2$ & $1 / 2$ & $1 / 2$ & $1 / 4$ & $1 / 4$ & خط الكتف الأمامي \\
\hline $181 / 2$ & $161 / 2$ & $141 / 2$ & $3 / 8$ & $3 / 8$ & عرض الظهر ه بوصة من أعلي نقطة من الكتف \\
\hline $111 / 2$ & 11 & $101 / 2$ & $1 / 4$ & $1 / 4$ & عمق الابط من الكتف ـ ـ ع \\
\hline 10 & $91 / 2$ & 9 & $1 / 4$ & $1 / 4$ & طول حردة الأبط مستقيمة \\
\hline $71 / 4$ & 7 & $63 / 4$ & $1 / 4$ & $1 / 4$ & قتحة الرقبة \\
\hline $43 / 4$ & $45 / 8$ & $41 / 2$ & $1 / 4$ & $1 / 4$ & قتحة الرقبة الامامية \\
\hline $11 / 8$ & 1 & 1 & $1 / 4$ & $1 / 4$ & عمق قتحة الرقبة الخلفية \\
\hline $3 / 4$ & $3 / 4$ & $3 / 4$ & $1 / 8$ & $1 / 8$ & أرتفاع الريب \\
\hline 31 & 30 & 29 & $1 / 2$ & $1 / 2$ & الطول الكلي \\
\hline
\end{tabular}


تقرير التعشيق للقى شيرت بقصات مقاس (S- M-L) عرض •^ سم

\begin{tabular}{|c|c|c|}
\hline \multicolumn{3}{|c|}{ معلومات العميل } \\
\hline اسم العميل & دكتور إيهاب & اسم المستخلم \\
\hline مقاسات التعشيق & M1:S(x1);M(x1);L(x1) & التاريخ / الوقت \\
\hline اسم الملف & CK under CRW -80 y.ord & \\
\hline
\end{tabular}

\begin{tabular}{|c|c|c|c|}
\hline \multicolumn{4}{|c|}{ معلومات التششيق } \\
\hline عرض الماركر & $80 \mathrm{~cm}$ & علد النمازج & 1 \\
\hline طول الماركر & \begin{tabular}{|l|l|}
5.07 & $\mathrm{~m}$ \\
\end{tabular} & علد القطع & 3 \\
\hline كفاءة التششيق & $8279 \%$ & | إجمالي علد الأجزاء & 22 \\
\hline & & |عددد الأجزاء المشقة & 22 \\
\hline
\end{tabular}

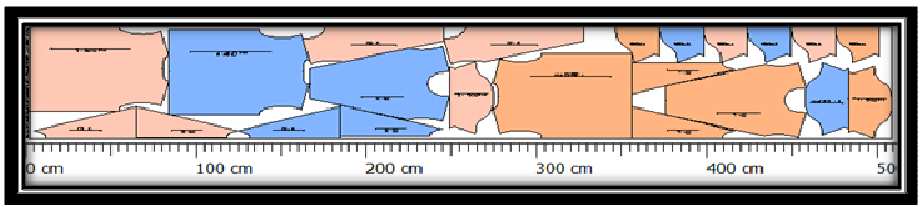

\begin{tabular}{|c|c|c|}
\hline وزن وحدة القياس & 180 & $\mathrm{G} / \mathrm{m} 2$ \\
\hline إجمالي وزن القماش & 0.73 & $\mathrm{KG}$ \\
\hline الوزن المستخدم & 0.6 & $\mathrm{~K}$ \\
\hline وزن الهالك & 0.13 & $\mathrm{KC}$ \\
\hline
\end{tabular}

تقرير التعشيق للقى شيرت بقصات مقاس (S- M-L) عرض •9 سم

\begin{tabular}{|c|c|c|}
\hline \multicolumn{3}{|c|}{ معلومات العميل } \\
\hline اسم العيل & دكتور إيهاب & اسم المستخدم - ام \\
\hline مقاسات التقشيق & $\mathrm{M} 1: \mathrm{S}(\mathrm{x} 1) ; \mathrm{M}(\mathrm{x} 1) ; \mathrm{L}(\mathrm{x} 1)$ & التاريخ / الوقت \\
\hline |سم الملف & CK under CRW 90 y.ord & \\
\hline
\end{tabular}

\begin{tabular}{|c|c|c|c|c|}
\hline \multicolumn{5}{|c|}{ معلومات التعشيق } \\
\hline عرض الماركر & 90 & $\mathrm{~cm}$ & عدد النمازج & 1 \\
\hline طول الماركر & 4.45 & $\mathrm{~m}$ & عدد القطع & 3 \\
\hline \multirow{2}{*}{ كفاءة التعشيق| } & \multirow{2}{*}{\multicolumn{2}{|c|}{$86.10 \%$}} & إجمالي عدد الأجزاء & 21 \\
\hline & & & عددد الأجزاء المعشقة & 21 \\
\hline
\end{tabular}

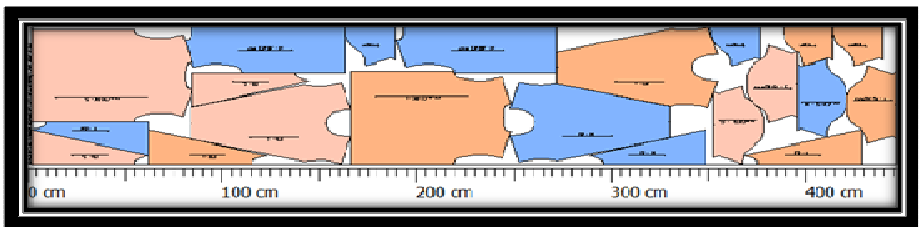

\begin{tabular}{|c|c|c|}
\hline وزن وحدة القياس & 180 & $\mathrm{G} / \mathrm{m} 2$ \\
\hline إجمالي وزن القماش & 0.72 & $\mathrm{KG}$ \\
\hline الوزن المستخدم & 0.6 & $\mathrm{KG}$ \\
\hline وزن الهالك & 0.12 & KG \\
\hline
\end{tabular}

تقرير التشيق للقى شيرت بقصات مقاس (S- M-L) عرض •10 سم
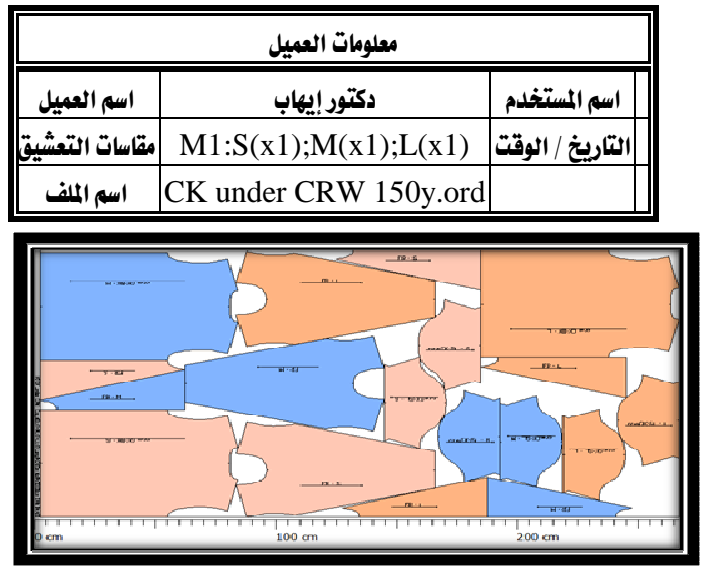

\begin{tabular}{|c|c|c|c|c|}
\hline \multicolumn{5}{|c|}{ معلومات التعشيق } \\
\hline عرض الماركر & 150 & $\mathrm{~cm}$ & عدد النمازج & 1 \\
\hline طول الماركر & 2.65 & $\mathrm{~m}$ & عدد القطع & 3 \\
\hline \multirow[t]{2}{*}{ كفاءة التصشيق| } & \multirow{2}{*}{\multicolumn{2}{|c|}{$84.47 \%$}} & إجمالي عدد الأجزاء & 18 \\
\hline & & & عددد الأجزاء المعشقة & 18 \\
\hline
\end{tabular}

\begin{tabular}{|c|c|c|}
\hline وزن وحدة القياس & 180 & $\mathrm{G} / \mathrm{m}^{2}$ \\
\hline إجمالي وزن القماش & 0.72 & $\mathrm{KG}$ \\
\hline الوزن المستخدم & 0.6 & $\mathrm{KG}$ \\
\hline وزن الهالك & 0.11 & KG \\
\hline
\end{tabular}

شكل رقم(r) يوضح تقرير التعشيق للتى شيرت بقصات مقاس (S- M-L) بثلاث عروض مختلفه 


\begin{tabular}{|c|c|c|c|c|c|c|c|c|c|}
\hline \multicolumn{3}{|c|}{ معدل الاستخدام } & \multicolumn{3}{|c|}{ كفاءه التقشيق } & \multirow{2}{*}{ فـى المداركر } & \multirow[t]{2}{*}{ المقاسات } & \multirow[t]{2}{*}{ القطعه } & \multirow[t]{2}{*}{ ค } \\
\hline معدل عرض رقم ץ & معدل عرض رقم r & |معدل عرض رقم 1 & | عرض رقم ب | & عرض رقم r & | عرض رقم & & & & \\
\hline או, r, سم & 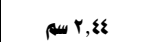 & & $\% \wedge \wedge, \imath$ & $\% \wedge \wedge, १ ६$ & $\% \wedge ৭, r \vee$ & $r$ & M L XL & البنطلون الأول & 1 \\
\hline س $r, \xi r$ & W T, YA & ع & $\% \wedge\rceil$, 「Y & $\% \wedge \Delta, 9 r$ & $\% \wedge \Delta, \vee 9$ & $r$ & M L XL & البنطلون الثانى & $r$ \\
\hline r. 79 & . & 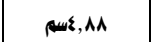 & $\%$ YO,Ar & $\%$ Ar,or & $\% \vee r, M$ & $r$ & M L XL & التى شيرت الأول & $r$ \\
\hline r.l & r ז \& سم & Nwo,n & $\% \mathrm{YA}, \mathrm{YA}$ & $\% \wedge \xi, \wedge \wedge$ & $\%$ \%r, II & $r$ & M L XL & التى شيرت الثانى & $\varepsilon$ \\
\hline س $r, q \xi$ & س \&, Y Y & (wo, 70 & $\%$ Y, Yo & $\% \wedge \Delta, 1 r$ & $\%$ ro, Ir & $r$ & S M L & التى شيرت الأول بدون قصات & 0 \\
\hline r, Toم & 0 \$ \& سم & م & $\% \wedge \xi, \& V$ & $\% \wedge 7,1$. & $\%$ Ar, ra & $r$ & S M L & التى شيرت الثانى بقصات & 7 \\
\hline
\end{tabular}

$$
\text { يتضح من الجدول رقم (^) مايلى: }
$$

أولا: البنطلون :

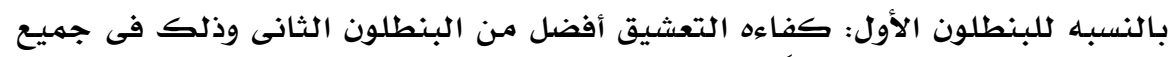

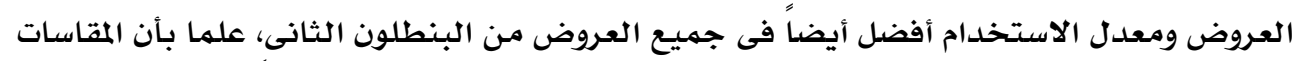

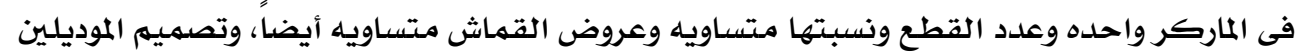

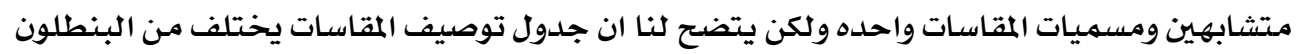

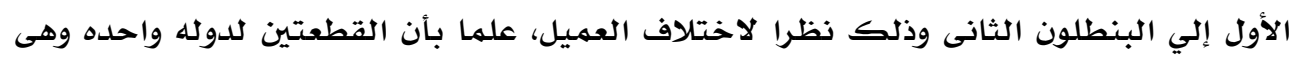

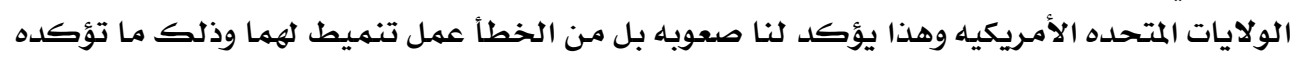

$$
\text { ثانيا: التى شيسه العمليه فى تلك القطعتين . }
$$

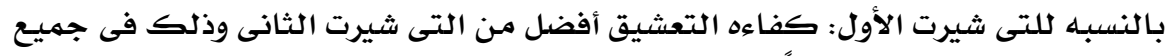

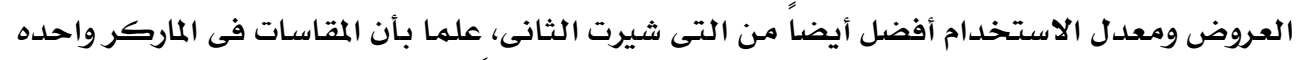

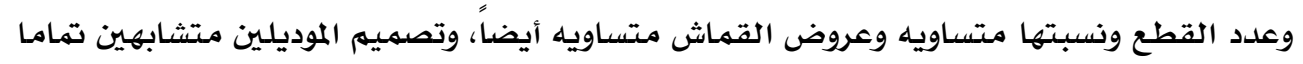

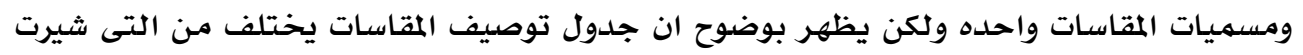

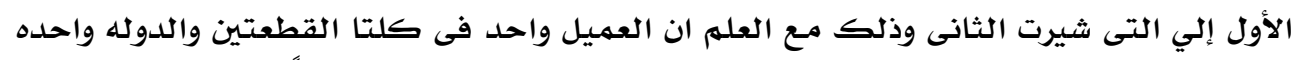

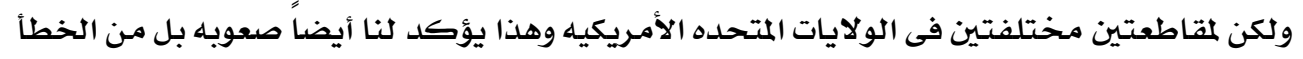

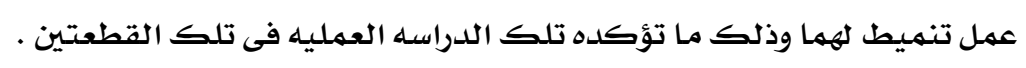
ثالثا: التى شيرت( بقصات ويدون قصدات ) :

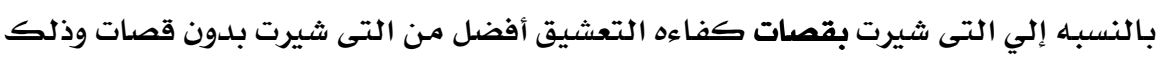

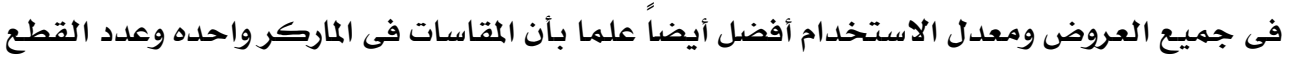

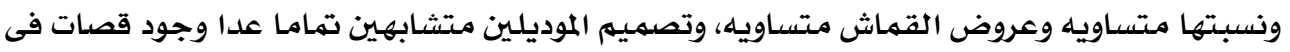

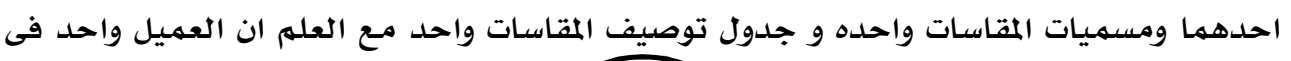




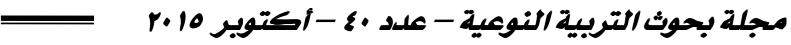

كلتا القطعتين والدوله واحده وهى احدى دول الاتحاد الاوريى ( المانيا ) ولكن اختلاف القصات

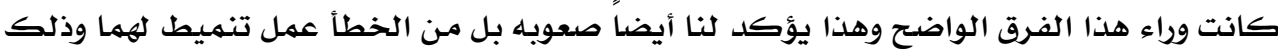

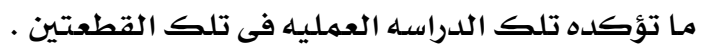

\section{المعالجة الإحصائية}

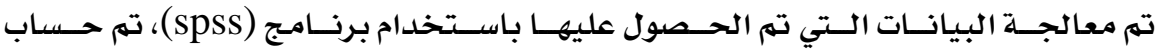

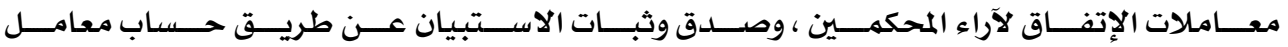

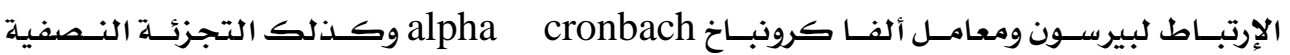

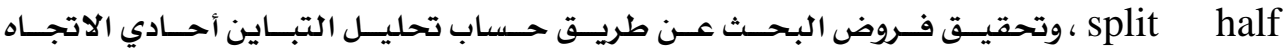

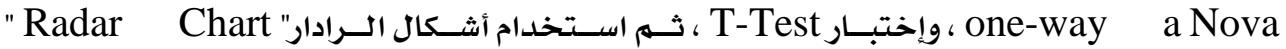

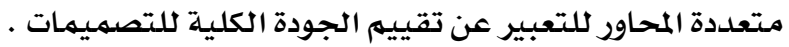

الصدق والثبات لبنود ومحاور استمارة الاستبيان :

ا- الصدق :

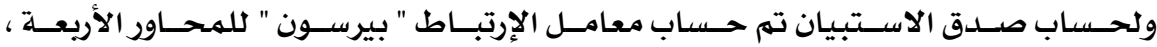

كما يلى:

جدول (ه) معامل الإرتباط " بيرسون" لمحاور الاستبيان الأربعة.

\begin{tabular}{|c|c|c|}
\hline الدلالة & الإرتباط & المحاور \\
\hline,$\cdot \cdot 1$ & $1, \cdots$ & المحور الأول : ما إمكانية تنميط معدل الاستخدام ونسبه الهالك في مجال تصلدير الملابس الجاهزة ؟ \\
\hline ,,$\cdot 1$ & , AOY & المحور الثانى : ما هي العوامل المترتبة على تنميط معدل الاستخدام ونسبه الهالك في مجال تصلير الملابس فى ع.م.ع ؟ \\
\hline , & , १९०० & المحور الثاثث : هل يتناسب تطبيق نظام التنميط لمعدل الاستخدام فى مجال تصلدير الملابس الجاهزة فى ع.م.ع ؟ \\
\hline , & •, 099 & المحور الرابع : هل يؤثر التنميط لمعدل الاستخدام ونسبة الهالك على الستثمر واللدولة والإقتصاد المصري ؟ \\
\hline
\end{tabular}

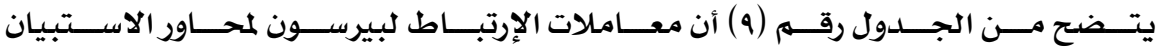

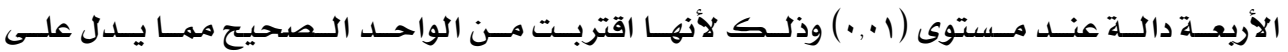
صدق وتجانس محاور الاستبيان الأربعة ، وصدق وتجانس الاند الاستبيان ككل . r- الثبات :

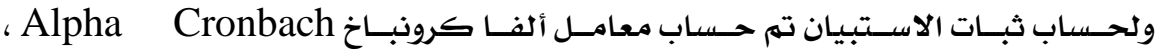

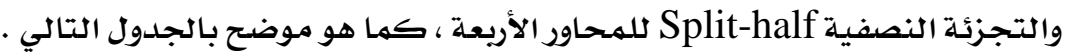




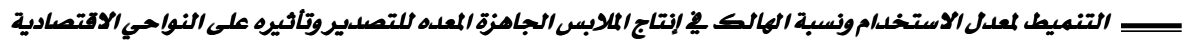
جدول (·•) معامل الثبات " Alpha , Split-half" لمحاور الاستبيان الأربع

\begin{tabular}{|c|c|c|}
\hline Split-half & Alpha & المحاور \\
\hline$\cdot$, VYY _., OYO & $\cdot$, 7ar & المحور الأول : ما إمكانية تنميط معدل الاستخدام ونسبه الهالك فى مجال تصدير الملابس الجاهزة ؟ \\
\hline$\cdot, \mathrm{V} \leqslant \mathrm{r}-\boldsymbol{*}, 011$ & $\cdot, \boldsymbol{T l t}$ & المحور الثانى : ما هي العوامل المترتبة على تنميط معدل الاستخدام ونسبه الهالك فى مجال تصدير الملابس فى ج.م.ع ؟ \\
\hline$\cdot, 70 \varepsilon \_, 0 r \cdot$ & $\cdot, 09 \mathrm{r}$ & المحور الثالث : هل يتناسب تطبيق نظام التنميط لمعدل الاستخدام فى مجال تصدير الملابس الجاهزة فى ج.م.ع ؟ \\
\hline$\cdot$, Aro_- YOr & $\cdot$, rrs & المحور الرابع : هل يؤثر التنميط لمعدل الاستخدام ونسبة الهالك على المستثمر والدولة والإقتصاد المصري ؟ \\
\hline 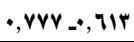 & $\cdot, 70$. & 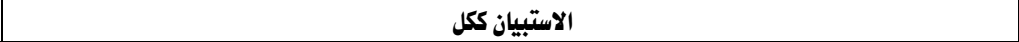 \\
\hline
\end{tabular}

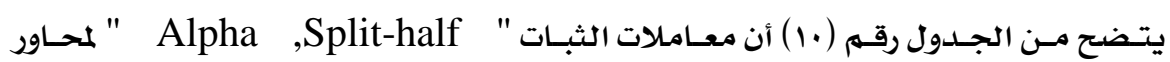

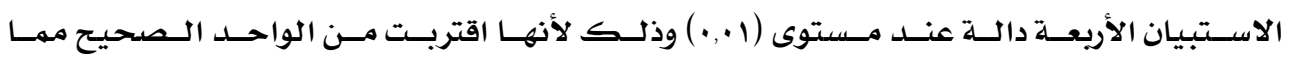

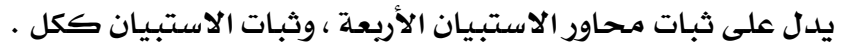
الفرض الأول :

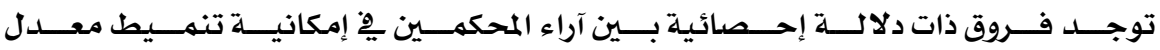

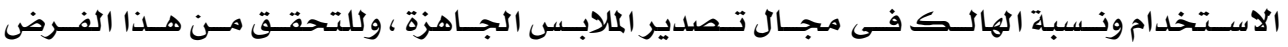

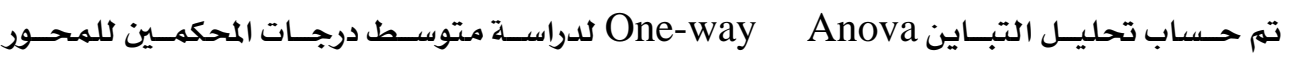
الأول ، كمما هو موضـح بالجدول التباين التالي .

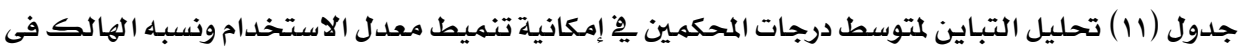
مجال تصدير الملابس الجاهزة

\begin{tabular}{|c|c|c|c|c|c|}
\hline Sig & $\mathrm{F}$ & متوسط المربعات & درجات الحرية & مجموع المربعات & \\
\hline \multirow{3}{*}{ •, qrv } & \multirow{2}{*}{ • } & $19 v, 111$ & $r$ & $\Delta 91$, rrr & بين المجموعات \\
\hline & & 1ราร, $77 v$ & $\wedge$ & IIVIr,rrr & داخل المجموعات \\
\hline & & & 11 & $\mid r r+\Lambda, 77 \mathrm{~V}$ & المجموع \\
\hline
\end{tabular}

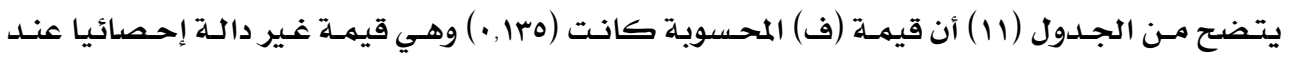

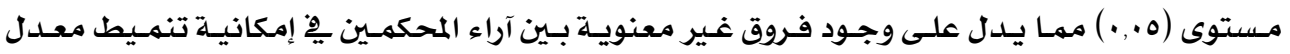

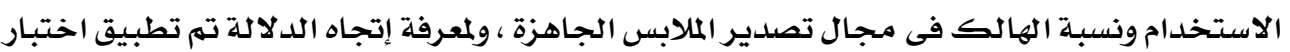

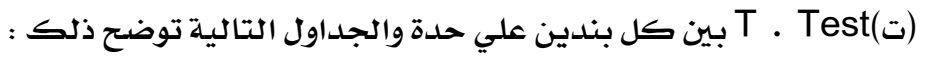




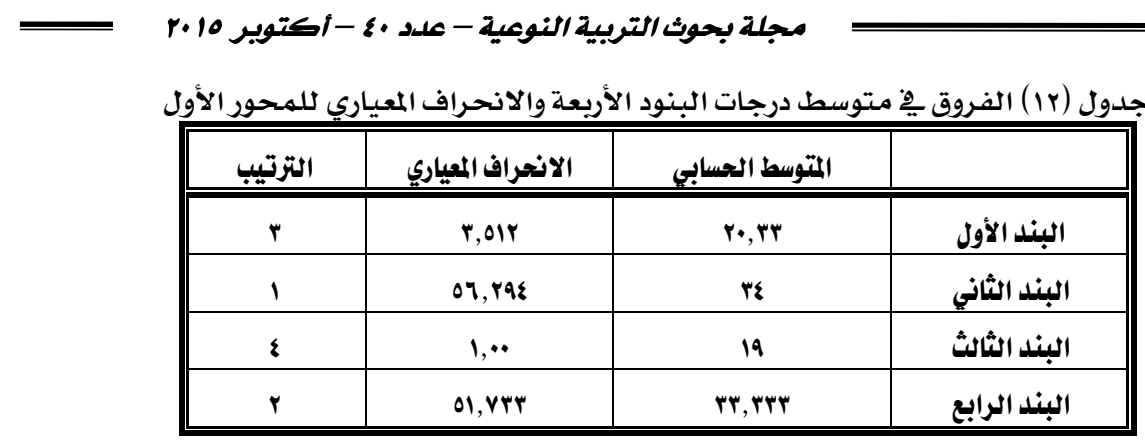

جدول (r) إختبـار T. Test بين كل بندين من البنود الخمسـة للمحور الأول

\begin{tabular}{|c|c|c|c|c|c|}
\hline Sig & قيمة (ت) & درجات الحرية & العينة & & \\
\hline$\cdot, 799$ & $\cdot, \llbracket \leqslant 7$ & r & $r$ & البند الثاني & البند الأول \\
\hline • ר Tro & $\cdot, 000$ & $r$ & $r$ & البند الثالث & \\
\hline$\cdot, 7 \wedge \wedge$ & $\cdot, \leqslant 7 \varepsilon$ & $r$ & $r$ & البند الرابع & \\
\hline •, 798 & $\cdot, \$ 00$ & $r$ & $r$ & البند الثالث & البند الثاني \\
\hline$\cdot, \wedge \xi \cdot$ & •, rrq & $r$ & $r$ & البند الرابع & \\
\hline •, YAr & $\cdot, \Sigma V Y$ & $r$ & $r$ & البند الرابع & البند الثالث \\
\hline
\end{tabular}

يتضع من الجداول السابقة :

• وجود فروق غير معنوية بين البند الأول والبند الثاني، حيث كانت قيمـة (ت) جعء, · وهي قيمـة غير دالة إحصائيا عند مستوي ه •, · ، لصدالح البند الثاني " يختلف التنميط لمعدل الاستخدام ونسبـة الهالك بأختلاف عروض الأقهمة المستخلدمـة " . • وجود فروق غير معنويـة بين البند الأول والبند الثالث، حيث كانت قيهـة (ت) 000, · وهي قيمسة

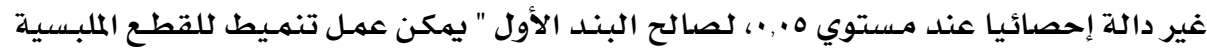
المختلفة الخاصدة بالتصدير يتناسب والإستهالاك ومعدل الاستخدام الفعلي" . • وجود فروق غير معنوية بين البند الأول والبند الرابع، حيث كانت قيمة (ت) ع7ع, • وهي قيمـة غير دالة إحصائيا عند مستوي ه •, · ، لصالح البند الرابع " يختلف التتهيط لمعدل الاستخدام باختلاف الدولة المصلدر إليها المنتج " . • وجود فروق غير معنوية بين البند الثاني والبند الثالث، حيث كانت قيمة (ت) 00ـ، · وهي قيمة غير دالة إحصائيا عند مستوي ه .. • ، لصائ البند الثاني " يختلف التتميط لمعدل الاستخدام

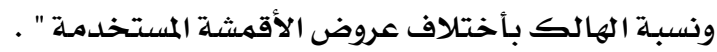

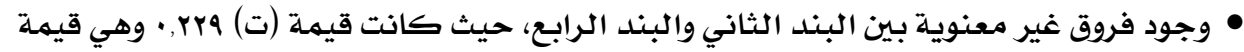
غير دالة إحصائيا عند مستوي ه ., ، ، لصالح البند الثاني " يختلف التتهيط لمعدل الاستخدام ونسبـة الهالك بأختلاف عروض الأقهمة المستخدمـة " . 


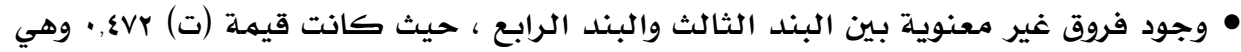

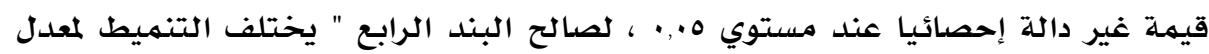

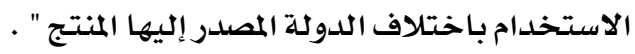

\section{الفرض الثاني :}

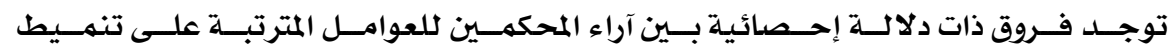

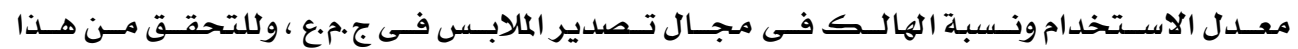

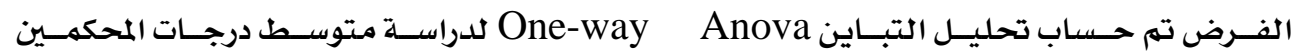

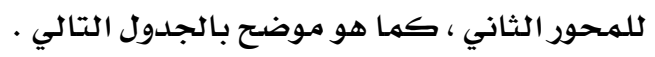

جدول (ع ) تحليل التباين لمتوسط درجات المحكمين يِّ العوامل المترتبة على تنميط معدل الاستخدام ونسبة الهالك فى مهال تصدير الملابس فى ج.م.ع

\begin{tabular}{|c|c|c|c|c|c|}
\hline Sig & $\mathrm{F}$ & متوسط المربعات & درجات الحرية & مجموع المربعات & \\
\hline \multirow{3}{*}{$\bullet, \wedge \bigcirc \wedge$} & \multirow{2}{*}{ - ror } & 1AY, arr & $r$ & $07 \cdot, 918$ & بين المجمهوعات \\
\hline & & $V \leqslant Y, V O$ & $\Lambda$ & 09\&Y & داخل المججموعات \\
\hline & & & 11 & $70 . r, 918$ & المجموع \\
\hline
\end{tabular}

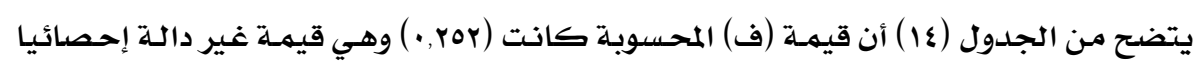

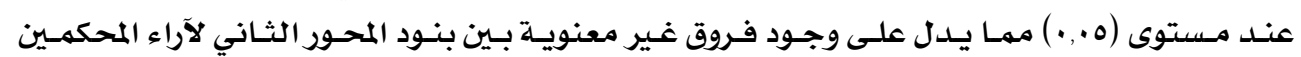

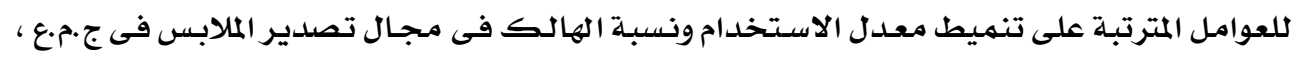

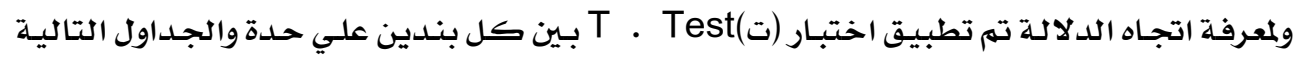
توضح ذلك : تمعرفة أجاه جدول (10) الفروق يْ متوسط درجات البنود الأربعة للمحور الثاني

\begin{tabular}{|c|c|c|c|}
\hline الترتيب & الانحراف المعياري & المتوسط الحسابي & \\
\hline 1 & $\varepsilon 9,79 r$ & rr, $774 \mathrm{r}$ & البند الأول \\
\hline$r$ & 19 & rq & البند الثاني \\
\hline$r$ & $\mathrm{v}, \mathrm{TrA}$ & $17,777 \mathrm{~V}$ & البند الثاث \\
\hline$\varepsilon$ & $9, \cdot v \varepsilon$ & 17, rrrr & البند الرابع \\
\hline
\end{tabular}




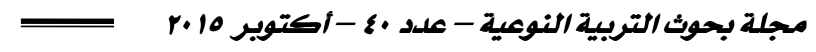

جدول (1 ) إختبار Test Tين كل بندين من البنود الخمسة للمحور الثاني

\begin{tabular}{|c|c|c|c|c|c|}
\hline Sig & قيمة (ت ) & درجات الحرية & العينة & & \\
\hline •, vฯv & •,rrq & r & $r$ & البند الثاني & البند الأول \\
\hline •, $1 \leqslant \vee$ & • OrT & $r$ & $r$ & البند الثالث & \\
\hline •, Irv & •, \&AY & $r$ & $r$ & البند الرابع & \\
\hline$\cdot \Delta \Lambda$. & $\cdot, 700$ & $r$ & $r$ & البند الثالث & البند الثاني \\
\hline$\cdot, 7 \cdot v$ & $\cdot, 7.0$ & $r$ & $r$ & البند الرابع & \\
\hline$\cdot, 901$ & $\cdot, \cdot 7$ & $r$ & $r$ & البند الرابع & البند الثالث \\
\hline
\end{tabular}

يتضح من الجداول السابقة :

• وجود فروق غير معنوية بين البند الأول والبند الثاني، حيث كانت قيمـة (ت) وسبr • وهي قيمسة

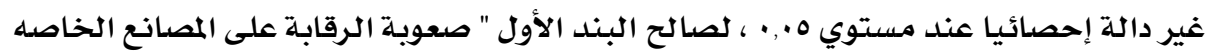

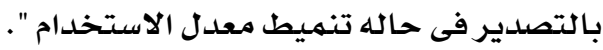

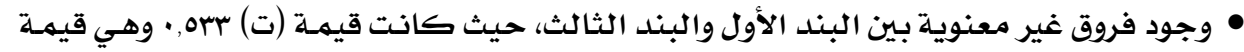

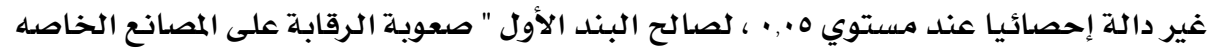

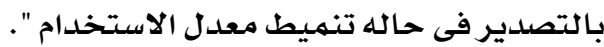

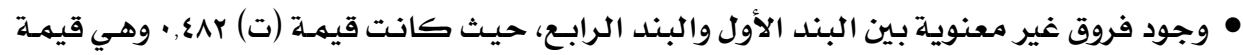

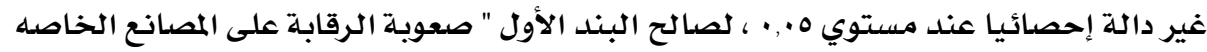

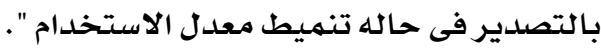

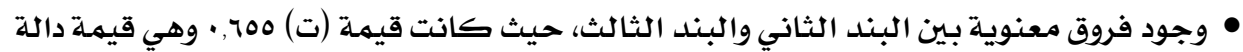

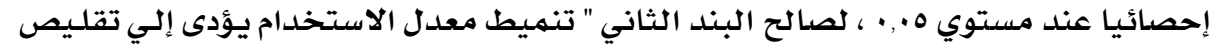

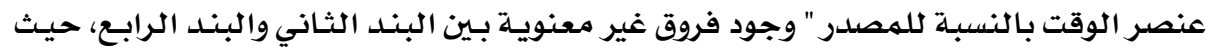

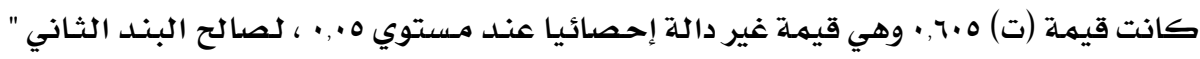

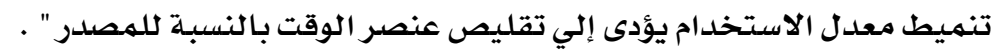

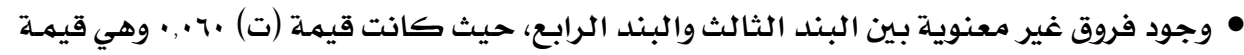

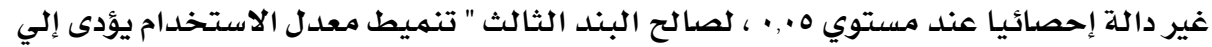
زيادة الصادارات ".

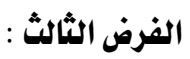

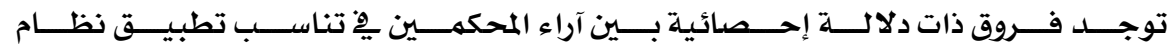

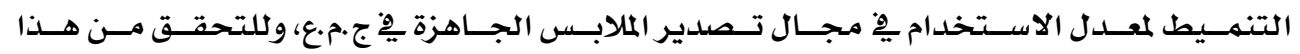

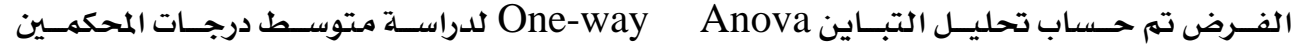

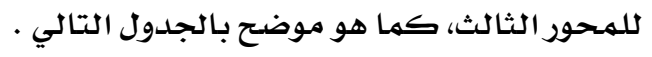




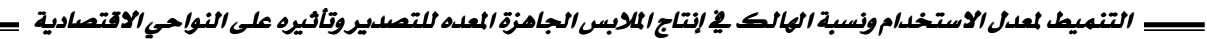

جدول (IV) تحليل التبـاين لمتوسط درجات المحكمين ٍِِ تناسب تطبيق نظام التنميط لمعدل الاستخدام

\begin{tabular}{|c|c|c|c|c|c|}
\hline Sig & $\mathrm{F}$ & متوسط المربعات & درجات الحرية & مجموع المربعات & \\
\hline \multirow{3}{*}{$\cdot, 90 \mathrm{~V}$} & \multirow{2}{*}{$\cdot, 1+1$} & 7, MrY & $r$ & $11,77 V$ & بين المجموعات \\
\hline & & $71,0.0$ & $\wedge$ & sqr & داخل المججموعات \\
\hline & & & 11 & $01 ., 77 \mathrm{~V}$ & المجموع \\
\hline
\end{tabular}

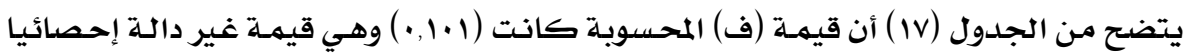

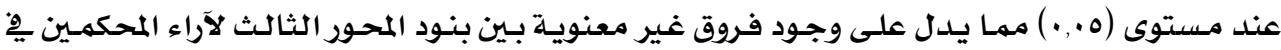

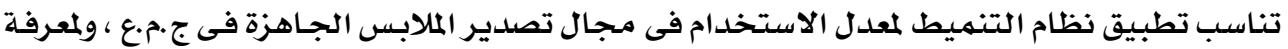

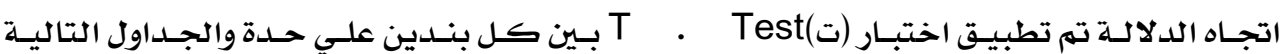
:توضح ذلك

جدول (1) الفروق يِّْ متوسط درجات البنود الأربعة للهـحور الثالث

\begin{tabular}{|c|c|c|c|}
\hline الترتيب & الانحراف المياري & المتوسط الحسابي & \\
\hline r & $r, \wedge \wedge \vee$ & IA,rrrr & البند الأول \\
\hline 1 & $r, 7 \leqslant 7$ & 19 & البند الثاذي \\
\hline$r$ & $11, \wedge \leqslant 7$ & IV, 7 ฯ & البند الثالث \\
\hline$\varepsilon$ & $9,0 . \xi$ & $10,777 \mathrm{~V}$ & البند الرابع \\
\hline
\end{tabular}

جدول (19) إختبـار T. Test بين كل بندين من البنود الأربعة للمهحور الثالث

\begin{tabular}{|c|c|c|c|c|c|}
\hline Sig & قيمة (ت ) & درجات الحرية & العينة & & \\
\hline$\cdot, \wedge \xi \cdot$ & •, rrq & r & $r$ & البند الثاني & البند الأول \\
\hline •, 9r9 & $\cdot, \bullet \wedge 7$ & r & $r$ & البند الثالث & \\
\hline -,OAr & $\cdot, 701$ & $r$ & $r$ & البند الرابع & \\
\hline •, Arv & $\cdot, r \leqslant q$ & r & $r$ & البند الثالث & البند الثاني \\
\hline •, 7 ro & $\cdot, 000$ & r & $r$ & البند الرابع & \\
\hline$\bullet, \wedge \varepsilon \cdot$ & •, rrq & r & $r$ & البند الرابع & البند الثاث \\
\hline
\end{tabular}

يتضع من الجداول السابقة :

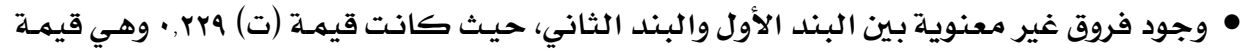

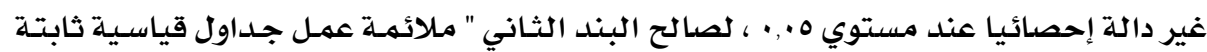
تختلف باختلاف عروض الاقمشة للقطع الملبسية المختلفة " .

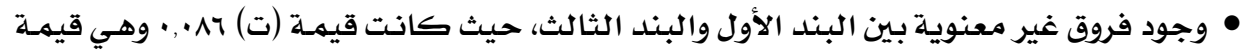

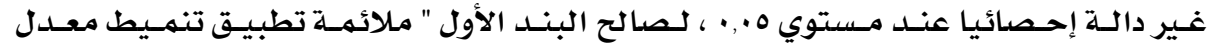

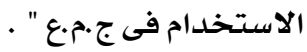




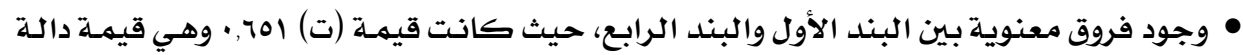

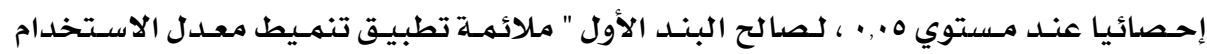

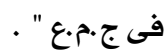
• وجود فروق غير معنوية بين البند الثاني والبند الثالث، حيث كانت قيمة (ت) و§؟ ، • وهي قيمة

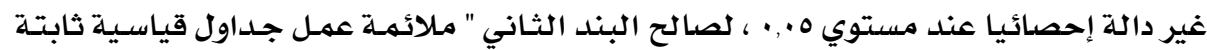
تختلف باختلاف عروض الاقمشة للقطع الملبسية المختلفة " . .

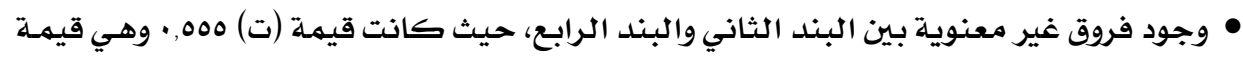

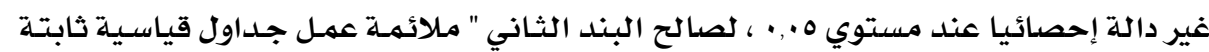

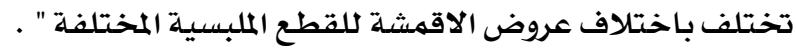

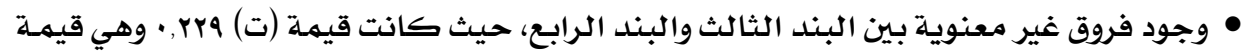

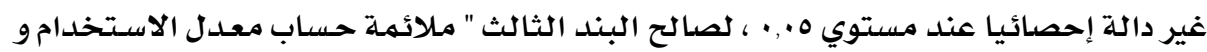
نسبة الهالك من خلال متوسطات لها " .

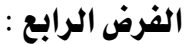

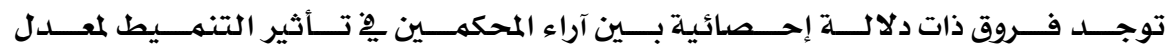

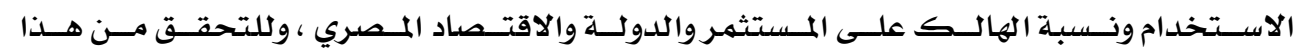

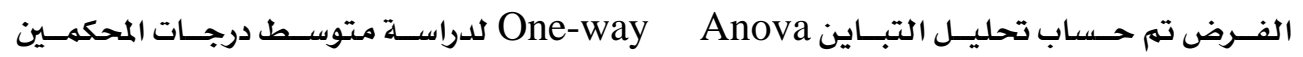

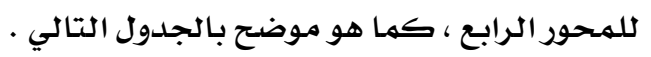

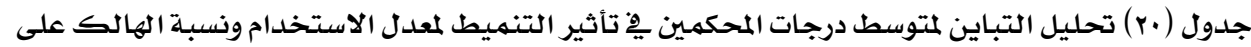
المستثمر والدولة والإقتصاد المصري

\begin{tabular}{|c|c|c|c|c|c|}
\hline Sig & $\mathrm{F}$ & متوسط المربعات & درجات الحرية & مجموع المربعات & \\
\hline \multirow{3}{*}{ •, Trr } & \multirow{2}{*}{ •,OHI } & $\varepsilon 9$ & $r$ & $1 \varepsilon V$ & بين المجموعات \\
\hline & & ar, ro & $\wedge$ & VrA & داخل المجموعات \\
\hline & & & 11 & $\wedge \wedge 0$ & المجموع \\
\hline
\end{tabular}

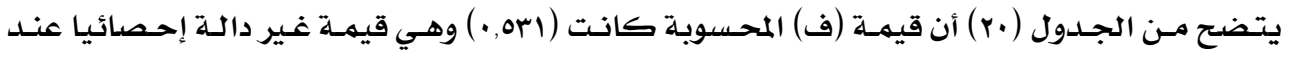

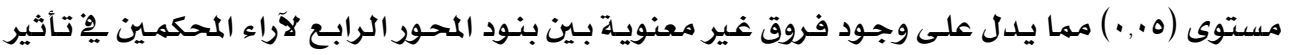

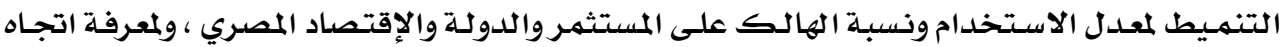

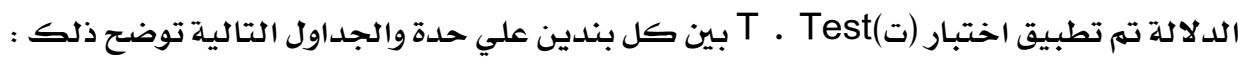


جدول (rا ) الفروق يِّ متوسط درجات البنود الأربعة للمحور الرابع

\begin{tabular}{|c|c|c|c|}
\hline الترتيب & الانحراف الميعياري & المتوسط الحسابي & \\
\hline 1 & $11,0 \leqslant V$ & rr,rrrr & البند الأول \\
\hline$r$ & $1 \cdot, 117$ & 10,rrrr & البند الثاني \\
\hline$r$ & $\{, \bullet \xi 1$ & r., rrre & البند الثالث \\
\hline$\varepsilon$ & I.,AlV & 10 & البند الرابع \\
\hline
\end{tabular}

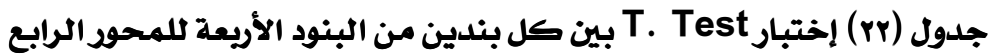

\begin{tabular}{|c|c|c|c|c|c|}
\hline الدلالة & قيمة (ت ) & درجات الحرية & العينة & & \\
\hline$\cdot, 011$ & $\cdot, 7 \xi$. & $r$ & $r$ & البند الثاني & البند الأول \\
\hline$\cdot, 0 \Lambda$. & •, 700 & $r$ & $r$ & البند الثالث & \\
\hline$\cdot, 011$ & •, Tor & $r$ & $r$ & البند الرابع & \\
\hline$\cdot, 097$ & צrT, & $r$ & $r$ & البند الثالث & البند الثاني \\
\hline$\cdot, \wedge \xi \cdot$ & - rra & $r$ & $r$ & البند الرابع & \\
\hline •,OAT & $\cdot, 7 \leqslant 9$ & $r$ & $r$ & البند الرابع & البند الثالث \\
\hline
\end{tabular}

\section{يتضح من الجداول السابقة :}

• وجود فروق معنوية بين البند الأول والبند الثاني، حيث كانت قيمسة (ت) • عا7, • وهي قيمـة دالـة

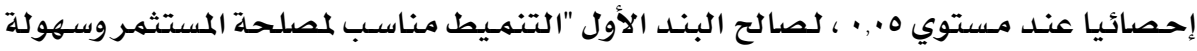

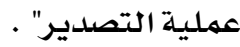

• وجود فروق معنوية بين البند الأول والبند الثالث، حيث كانت قيمـة (ت) 700, • وهي قيمـة دالـة

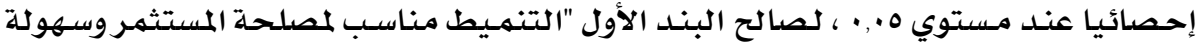

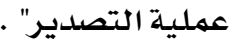

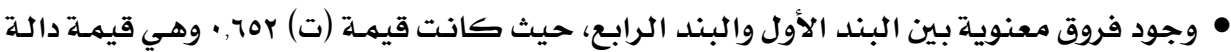

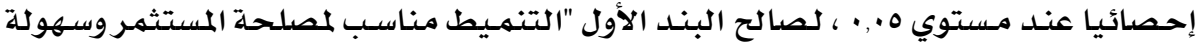

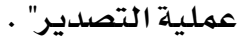

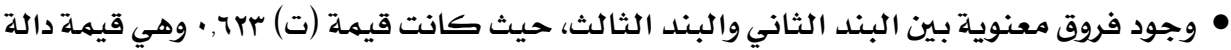

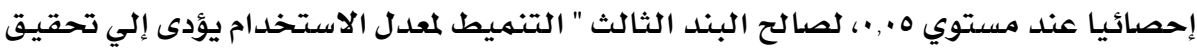

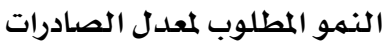

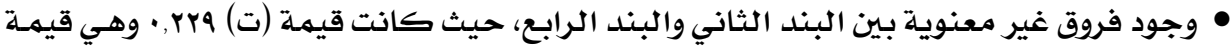

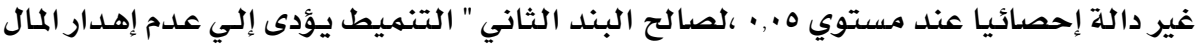

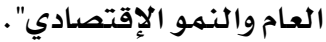


• وجود فروق معنوية بين البند الثالث والبند الرابع، حيث كانت قيمة (ت) هـا7, • وهي قيمة دالة

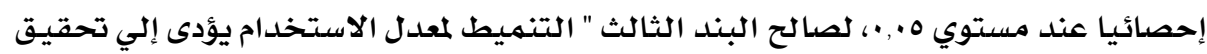

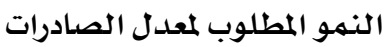

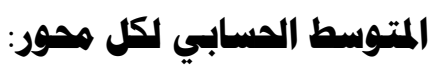

ا- متوسط تقييم بنود المحور الأول :

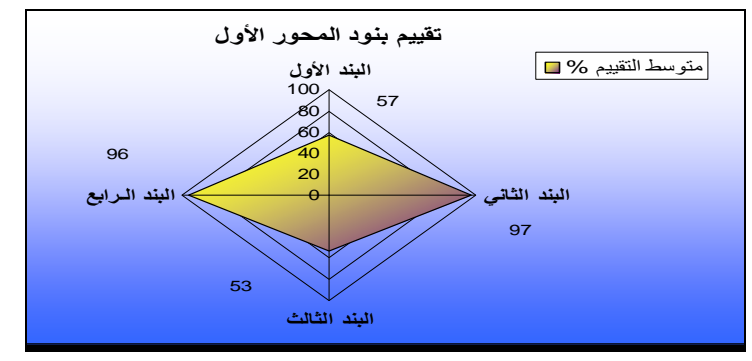

شكل(r) الفروق ِِّ متوسطات درجات المحكمين لبنود المحور الأول

من الجدول رقم (rr) والشكل الراداري رقم (rا ) نستخلص أن:

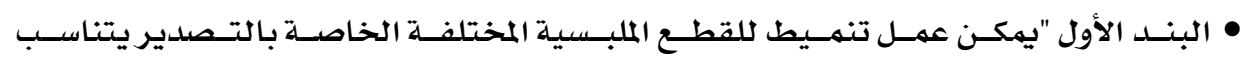

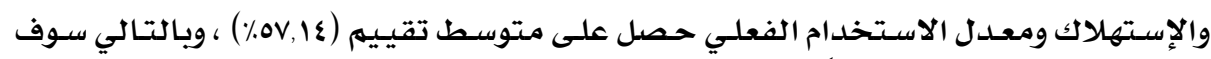
يكون تحقيق هذا البند ضعيفاً

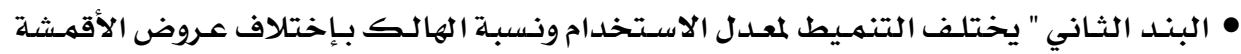

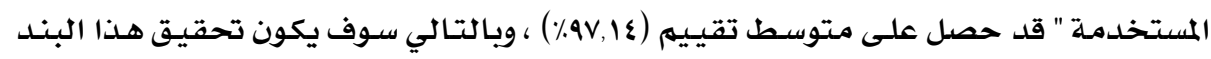
متميز

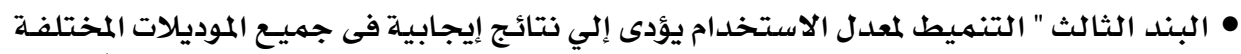

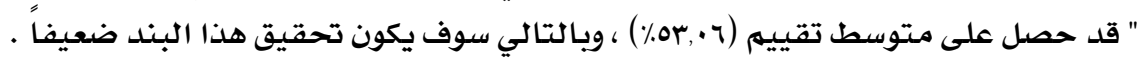

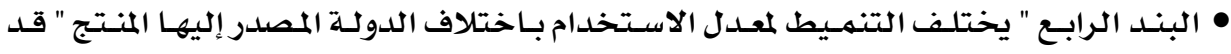

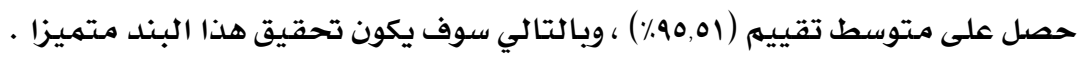
: ب - متوسط تقييم بنود المحور الثاني

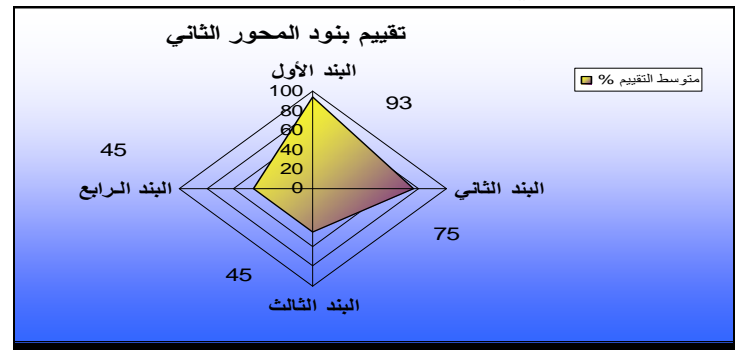

شكل (£ 1) الفروق بِّ متوسطات درجات المحكمين لبنود المحور الثاني 


$$
\text { من الجدول رقم (rr) والشكل الراداري رقم (عا ) نستخلص أن: }
$$

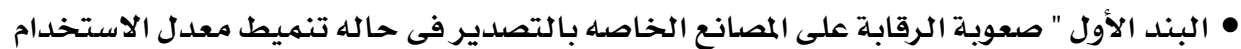

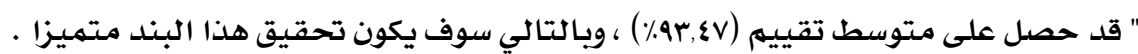

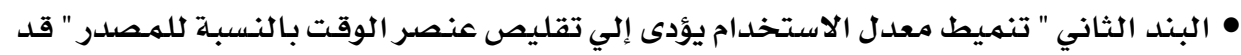

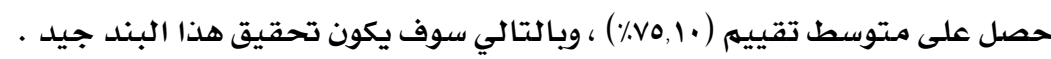

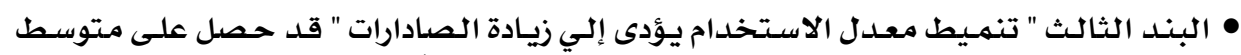

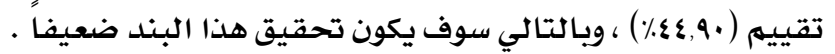

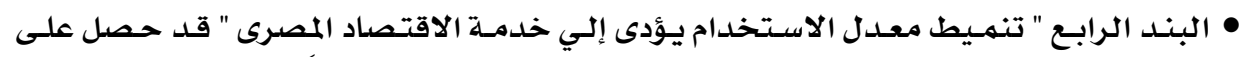

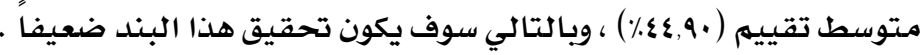

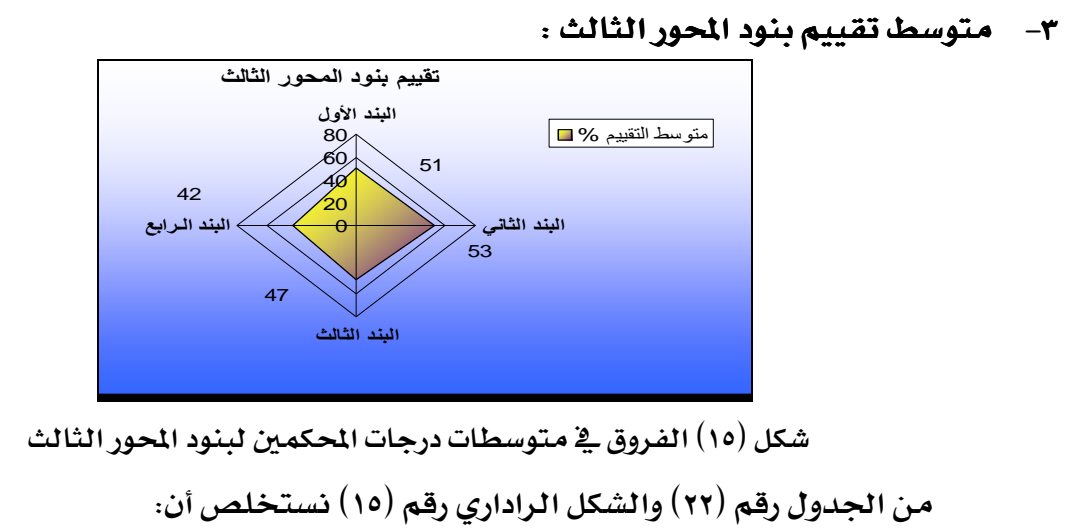

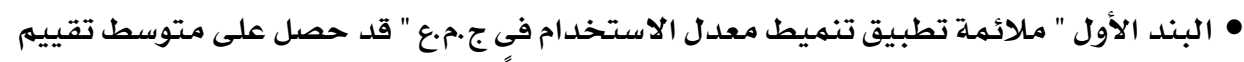

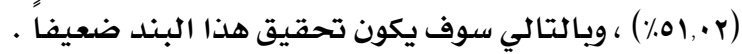

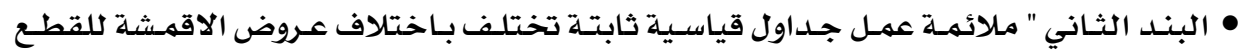

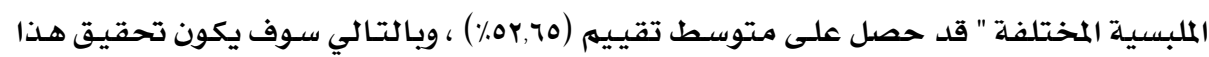

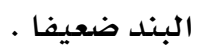

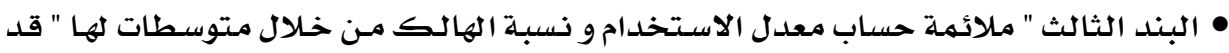

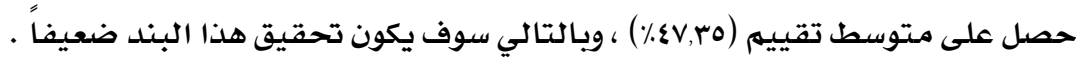

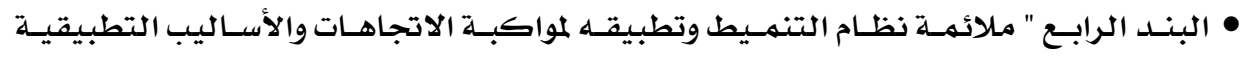

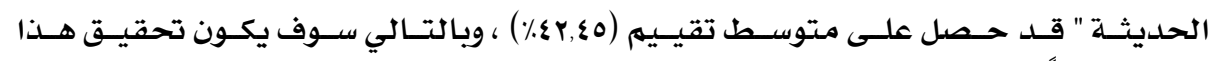




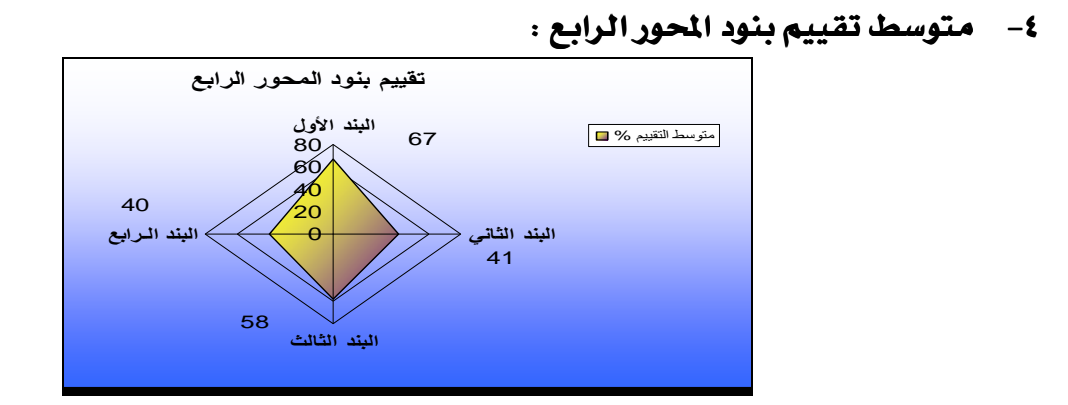

شكل (17) الفروق يِّ متوسطات درجات المحكمين لبنود المحور الرابع

من الجدول رقم (rr) والشكل الراداري رقم (17) نستخلص أن:

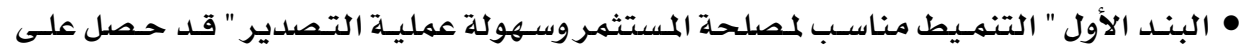

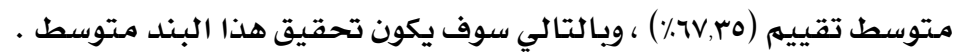

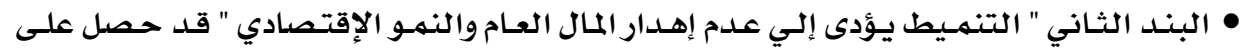

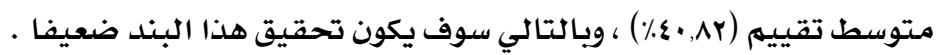

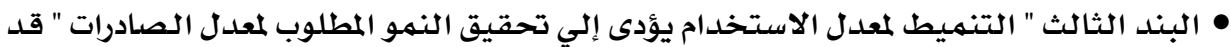

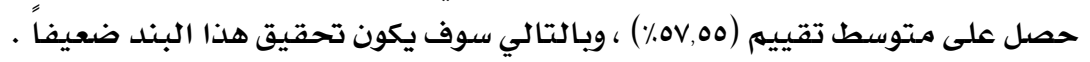

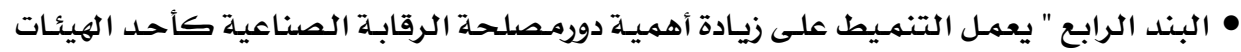

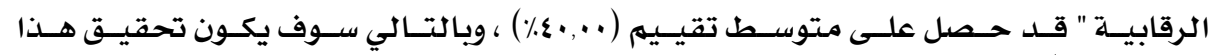

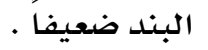

\section{من خلال عرض النتائج السابقه نستنتج الآتى:}

ا ـ لا يمكن عمل تنميط للقطع الملبسية المختلفة الخاصـة بالتصدير لمعدل الاستخدام ونسبه

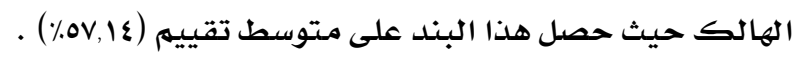

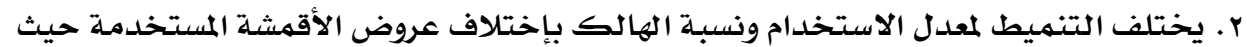

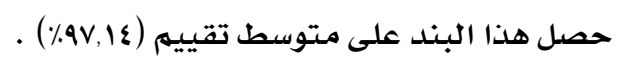

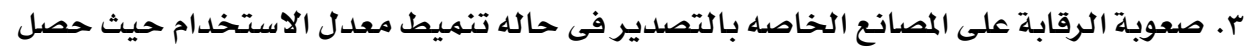

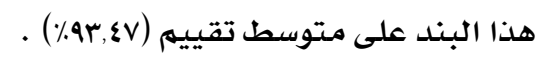

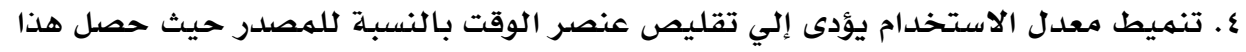

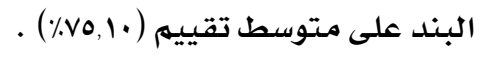

ه. تنميط معدل الاستخدام لا يؤدى إلي زيادة الصـادارات حيث حصل حصل هذا البندلد على متوسط

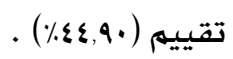

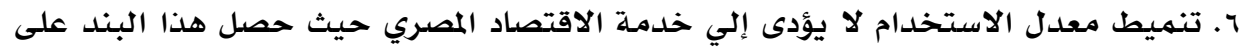

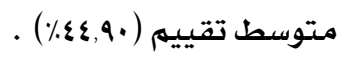




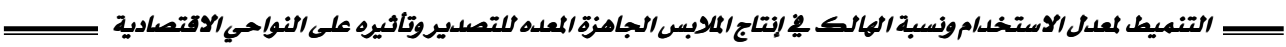

V. عدم ملائمهة تطبيق تنهيط معدل الاستخدام فى ج.م.ع حيث حصل هذا البند على متوسط

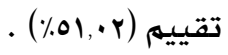

^. علدم ملائمهة عمل جداول قياسية ثابتة تختلف باختلاف عروض الأقمشة للقطع الملبسية المختلفة حيث حصل هذا البند على متوسط تقييم (0r,0r\%) .

9. عدم مـلائمسة حسـاب معدل الاستخدام و نسبـة الهالك من خلال متتوسطات لها حيث حصل هذا

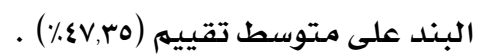

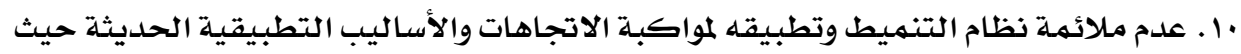

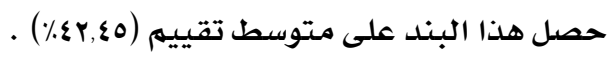

الـ لا يعمل التتهيط على زيـادة أهمية دور مصلحة الرقابة الصناعية كأحد الهيئات الرقابية

$$
\text { حيث حصل على متتوسط تقييم ( . . • ع٪) . . . }
$$

ا- ضـرورة التوسـع يِّ الأبحاث الخاصسة بعمليات تصدير الملابس الجـاهزة لما لها مـن تأثير مباشر

$$
\text { علي زيادة الدخل القومي للدولية. }
$$

r- إلقاء الضوء الهام الذي يلعبـه القائمهين علي البحث العلمي يِّ اكتشاف وتحليل المشكلات المتعلقة بهـجال الملابس للوصول إلي نتائج علميلة تخدم المجتهـع وبيهن تطبيقها . r- ضرورة تواجد الرقابـة المستهمرة علي المصانع من قبل مصلحة الرقابـة الصناعية للتأكد من

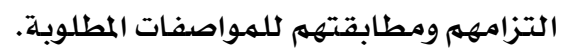

ع- يوصي الباحث أصحاب المصانع المصدرة ومسئولي الرقابة الصناعية بضرورة الأخذ بكل الطرق العلميـه لخدمـه ذلك القطاع الكات الهام.

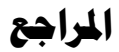

ا ـ أحمد رمزي أحمد: "آليات مساعدة الصناعات الصغيرة والمتوسطة ِِّ مجال صناعة الملابس الجاهزة" -

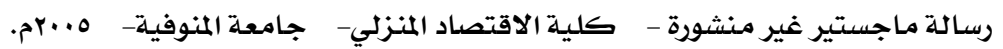

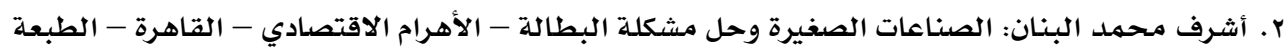

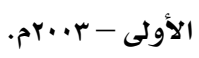

r. النشرة الشهريـة لمنتجات التصدير المصرية - تصدر عن مـركز المعلومات ودعم اتخاذ القرار بمجلس الوزراء

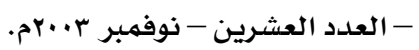

ع. إيهان فاروق عمر الفرماوي: "إمكانية تطوير قسه العينات بهصانع الملابس الجاهزة بـمـج المنظومـة الإنتاجية لبعض مـراحل إنتاج البنطلون الجينز باستخدام الطرق التكنولوجية الحلديثة" - رسالة

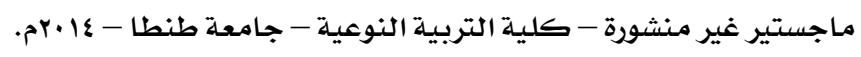

ه. إيمان محمد حسن: " تفعيل دور المنتجين ِِ تسويق منتجاتهم من الملابس الجاهزة ِِّ ظل المتغيرات

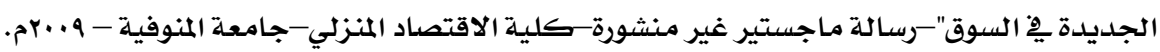


ב-2

1. بوسي حمدي فرحات: "دور التجارة الإلكترونية ِِّ زيادة معدل صادرات مصر من الملابس الجاهزة

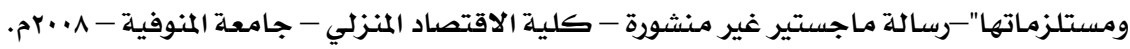

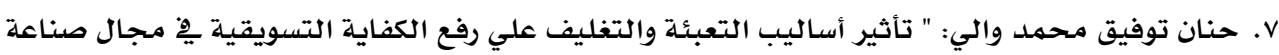

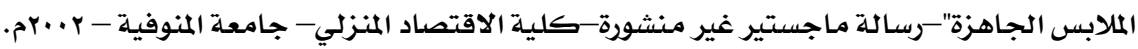

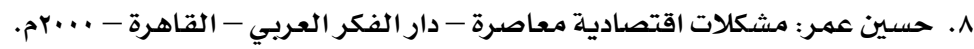

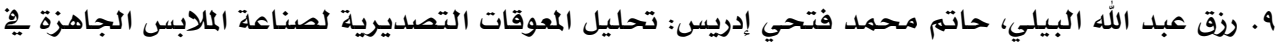

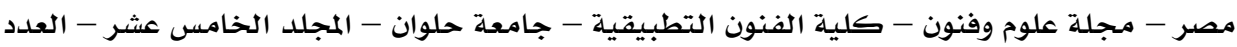

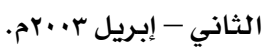

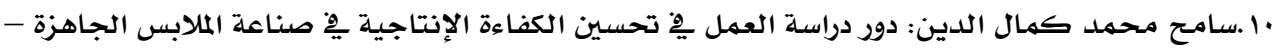

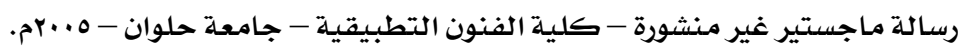

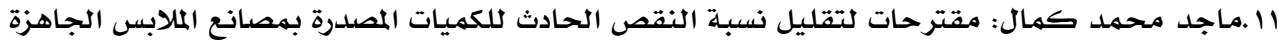

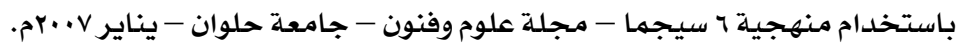

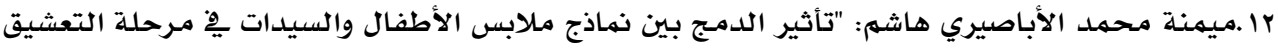

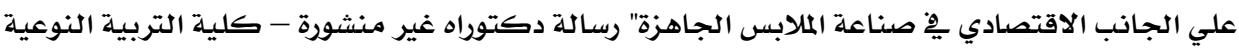

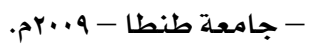

سا .نجلاء محمد عبد الخالق: "تحديد أنسب المعايير القياسية لجودة تقنيات تصنيع الملابس الجاهزة" - رسالة

$$
\text { دكتوراه غير منشورة - كلية الاقتصاد المنزلي - جامعة المنوفية - ؟ .. بrم. }
$$

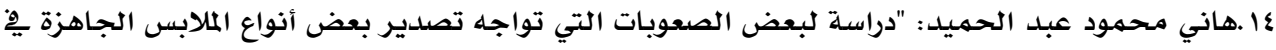

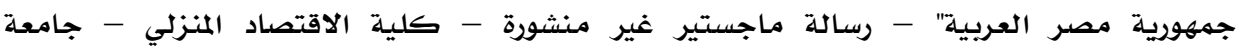

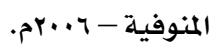

10.هالة محمد لبيب: إدارة المشروعات الصغيرة ِِّ الوطن العربي دليل عملي لكيفية البدء بمشروع صغير

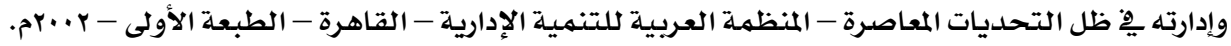

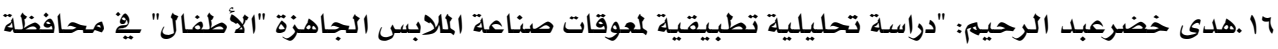

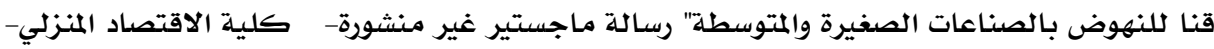

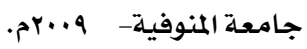

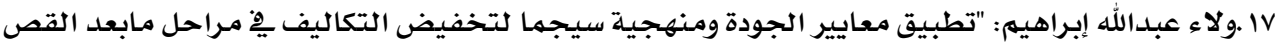

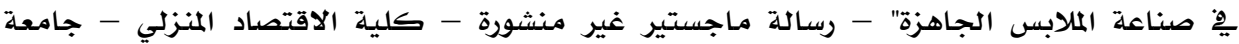

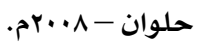

18. Philip Kotler: "Marketing Management, Analysis, Planining and control, prentice - Hall, Inc., New Jersey, 1984.

19. Pyzdex, Thomas: The six sigma Project Planner, NewYork: Mc Graw- Hill, 2003. 


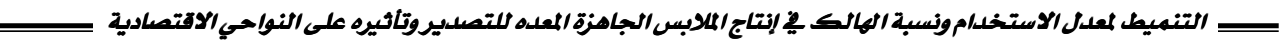

20. Toyn. W., "Testing and quality assurance" The textile in stitute Asia and World textiles, world conference, Hong Kong, 1993.

21. WWW.sooqmasr.net

22. www.quzegypt.gov.eg/About- The Qualifying Industrial

23. www.wisegeek.com

24. www.masress.com 
Profiling The Utilization Rate And The Proportion Of The Deceased In The Production Of Garments Intended For Export And Its Impact On Economic Aspects

\section{Abstract:}

The export considered of the most important incursion strategies in international markets, and is one of the most important economic objectives of the countries and factories of ready-made garments alike, in order to achieve further development in the field of ready-made garments industry in Egypt in general and in the export of clothing in particular, should be held on the scientific basis as well as the participation of workers in the field of scientific research in the study of recent developments in all aspects of that industry and choose what fits with our society and its development and work to apply it in practice until there is sophisticated methods achieve a measure of the required export growth to reach to competition in global markets, where the State shall give consideration for those giant industry and provide it with a lot of financial support through the provision of various raw materials from foreign markets and allow once to enter the countries without any customs duty either by temporary admission or drawback so that the factories can produce those raw materials and reexport and even giving financial support to the size of those export operations after good observation of the process of production and export through trained system, hence the research aims to study profiling the utilization and the proportion of the deceased in the production of garments for export and its impact on economic aspects to access to the possibility of its application or not and impacts on the economic aspects, where the researcher studying the process for some descriptions tables of some garment pieces exporting outside and with the same measurements and analyzed it and made the marker of it to compare utilization rates for the same sizes from client to another and made a questionnaire for arbitration of those results and the possibility of the application of its own profiling rate, the research results achievable for its aims. 